Atmos. Chem. Phys., 17, 14119-14143, 2017

https://doi.org/10.5194/acp-17-14119-2017

(c) Author(s) 2017. This work is distributed under

the Creative Commons Attribution 3.0 License.

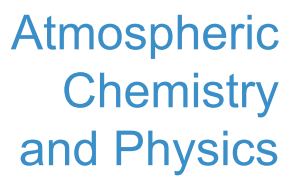

(c) (i)

\title{
Long-path measurements of pollutants and micrometeorology over Highway 401 in Toronto
}

\author{
Yuan You ${ }^{1}$, Ralf M. Staebler ${ }^{1}$, Samar G. Moussa ${ }^{1}$, Yushan $\mathrm{Su}^{2}$, Tony Munoz ${ }^{2}$, Craig Stroud ${ }^{3}$, Junhua Zhang ${ }^{3}$, and \\ Michael D. Moran ${ }^{3}$ \\ ${ }^{1}$ Air Quality Processes Research Section, Environment and Climate Change Canada, Toronto, Ontario, M3H 5T4, Canada \\ ${ }^{2}$ Ontario Ministry of the Environment and Climate Change, Toronto, Ontario, M9P 3V6, Canada \\ ${ }^{3}$ Air Quality Modelling and Integration Section, Environment and Climate Change Canada, Toronto, \\ Ontario, M3H 5T4, Canada
}

Correspondence to: Ralf M. Staebler (ralf.staebler@canada.ca)

Received: 7 April 2017 - Discussion started: 3 May 2017

Revised: 27 September 2017 - Accepted: 6 October 2017 - Published: 28 November 2017

\begin{abstract}
Traffic emissions contribute significantly to urban air pollution. Measurements were conducted over Highway 401 in Toronto, Canada, with a long-path Fourier transform infrared (FTIR) spectrometer combined with a suite of micrometeorological instruments to identify and quantify a range of air pollutants. Results were compared with simultaneous in situ observations at a roadside monitoring station, and with output from a special version of the operational Canadian air quality forecast model (GEM-MACH). Elevated mixing ratios of ammonia (0-23 ppb) were observed, of which $76 \%$ were associated with traffic emissions. Hydrogen cyanide was identified at mixing ratios between 0 and $4 \mathrm{ppb}$. Using a simple dispersion model, an integrated emission factor of on average $2.6 \mathrm{~g} \mathrm{~km}^{-1}$ carbon monoxide was calculated for this defined section of Highway 401, which agreed well with estimates based on vehicular emission factors and observed traffic volumes. Based on the same dispersion calculations, vehicular average emission factors of 0.04 , 0.36 , and $0.15 \mathrm{~g} \mathrm{~km}^{-1}$ were calculated for ammonia, nitrogen oxide, and methanol, respectively.
\end{abstract}

\section{Introduction}

In 1996, 45.2\% of the population of Toronto, Canada's largest city, lived within $500 \mathrm{~m}$ of a highway or within $100 \mathrm{~m}$ of a major road (HEI, 2010). This percentage was updated to $40 \%$ in 2002 and 2005 (Su et al., 2015). Therefore, a significant portion of the population is exposed to traffic-related air pollution. Pollutants that have been previously reported from motor vehicles include nitrogen oxides $\left(\mathrm{NO}_{x}\right)$, carbon monoxide (CO), ultrafine particles, $\mathrm{PM}_{2.5}$, black carbon, volatile organic compounds (VOCs), semi- and low-volatile organic compounds, aromatics, polycyclic aromatic hydrocarbons (PAHs), and greenhouse gases (Brugge et al., 2007; Zhou and Levy, 2007; Karner et al., 2010, Gentner et al., 2012, 2017; Popa et al., 2014). Motor-vehicle-related emissions contributed about $40 \%$ of the $\mathrm{PM}_{2.5}$ in Toronto during 2000 to 2001 according to Lee et al. (2003). A study on a global scale indicated that traffic emissions are important contributors to outdoor air pollution (ozone $\left(\mathrm{O}_{3}\right)$ and $\mathrm{PM}_{2.5}$ ) associated with premature mortality in 2010 for the USA, Germany, and the UK (Lelieveld et al., 2015).

Exposure to these air pollutants is associated with negative health effects. Laboratory studies have indicated that inhalation of fine particles and $\mathrm{O}_{3}$ even for a short time causes acute conduit artery vasoconstriction (Brook, 2002). Studies in Toronto have shown that exposure to traffic-related air pollution is associated with respiratory conditions (Buckeridge et al., 2002), increased risk of circulatory mortality (Jerrett et al., 2009), cardiovascular mortality (Chen et al., 2013), ischemic heart disease (Beckerman et al., 2012), and childhood atopic asthma (Shankardass et al., 2015). Research results in other locations have also shown associated negative health effects, such as asthma (Lin et al., 2002; McConnell et al., 2006), cancer and leukemia (Pearson et al., 2000) in children, and development of obesity in children (Jerrett et al., 2014). Exposure to traffic-related air pollution may also be 
associated with increased risk of dementia. Chen et al. (2017) studied a large adult population of Ontario between 2001 and 2012, and they found that incident dementia was $7 \%$ higher for people living within $50 \mathrm{~m}$ away from major roads than for the general population.

The segment of Highway 401 crossing Toronto is the busiest highway in North America, with annual average daily traffic counts of 410000 (Ontario Ministry of Transportation, 2016). A few studies on air pollution have been conducted near Highway 401 in the Greater Toronto Area in the past. Beckerman et al. (2008) measured air pollutants at the same location as the current study presented here. They showed elevated nitrogen dioxide $\left(\mathrm{NO}_{2}\right)$ and VOCs levels both upwind and downwind of Highway 401, and pollutants did not decay to background levels until 300-500 $\mathrm{m}$ downwind.

One focus of this study was to measure gaseous pollutants from a highway segment with very high traffic through the use of a long-path Fourier transform infrared (FTIR) spectrometer for 16 days. Compared to offline post-analytical methods, FTIR spectroscopy can determine mixing ratios (also referred to as "mole fractions") of a variety of gaseous pollutants in near-real time simultaneously, without a container or tubing and without experimental contamination after sampling (Griffith and Jamie, 2000). Another advantage of long-path FTIR spectroscopy is that it retrieves pathaveraged mixing ratios instead of point measurements, so it is less dependent on wind direction. A common approach to retrieve mixing ratios of species from FTIR measurements is to compare the measured spectra with reference spectra obtained in the laboratory at a given temperature and pressure with a known mixing ratio. The Pacific Northwest National Laboratory (PNNL) established a database of gas-phase infrared spectra for pure compounds (Sharpe et al., 2004; Johnson et al., 2010). Another source of reference spectra is the molecular absorption database HITRAN (HIgh resolution TRANsmission molecular absorption database) (Rothman et al., 1998, 2013). A major weakness of FTIR spectroscopy is the interference from water vapour, which can be too strong for some species and some absorption features, for example when quantifying mixing ratios of nitrogen oxide (NO) and $\mathrm{NO}_{2}$ in a humid environment.

FTIR spectroscopy has been used to quantify the mixing ratios of various trace species emitted by forest biomass burning (Griffith et al., 1991; Yokelson et al., 1996, 1997, 2007, 2008, 2013; Goode et al., 1999; Yokelson, 1999; Burling et al., 2010; Johnson et al., 2010; Akagi et al., 2013, 2014; Paton-Walsh et al., 2014; Smith et al., 2014), volcanoes (Horrocks et al., 1999; Oppenheimer and Kyle, 2008), industrial parks (Wu et al., 1995), and in urban areas (Grutter et al., 2003; Hong et al., 2004; Coleman et al., 2015). FTIR spectroscopy was also used in flux measurements by the gradient technique at agriculture sites (Griffith and Galle, 2000). High-resolution FTIR spectroscopy has also been used to obtain ozone profiles in the Canadian Arctic (Lindenmaier et al., 2010). Vehicle emissions have also been investigated in a tunnel by open-path FTIR spectroscopy (Bishop et al., 1996; Popa et al., 2014). Bradley et al. (2000) performed a 3-hour measurement in the morning beside a road in Denver using long-path FTIR spectroscopy and quantified mixing ratios of $\mathrm{CO}$, carbon dioxide $\left(\mathrm{CO}_{2}\right)$, and nitrous oxide $\left(\mathrm{N}_{2} \mathrm{O}\right)$. Grutter et al. (2005) measured the formaldehyde mixing ratios by open-path FTIR spectroscopy in downtown Mexico City in 2003 and compared it with a point measurement at the same site.

There are very few studies, however, that combine direct measurements of mixing ratios of gas-phase pollutants from highway emissions with detailed information on the micrometeorology at the same time and same location. Micrometeorological conditions will be shown here to have a significant effect on modulating the observed mixing ratios. Baldauf et al. (2008) studied the effect of traffic emission and meteorological conditions on the local air quality near a road in Raleigh, North Carolina, USA, in 2006 using long-path FTIR spectroscopy. Brachtl et al. (2009) measured PAH mixing ratios along with $\mathrm{CO}$, sulfur dioxide $\left(\mathrm{SO}_{2}\right), \mathrm{NO}_{x}$, and $\mathrm{PM}_{2.5}$ at roadside for 4 days in Quito, Ecuador. An early morning peak followed by a sharp drop of mixing ratios was observed, corresponding to the sharp increase of solar irradiation after 07:00 LT (UTC $-5 \mathrm{~h})$. Their results also showed another weaker peak of $\mathrm{CO}, \mathrm{NO}_{x}$, and $\mathrm{PM}_{2.5}$ between 20:00 and 21:00, after solar irradiation decreased to zero and temperature dropped. Other studies monitored ambient temperature and wind speed to understand meteorological and mixing conditions, and changes in pollutant mixing ratios were found to correlate with these conditions. Gentner et al. (2009) measured $\mathrm{CO}$ and $\mathrm{VOC}$ mixing ratios $1 \mathrm{~km}$ from a highway for 2-month-long periods in Riverside, California, in 2005. They attributed the minimum $\mathrm{CO}$ mixing ratios observed in the afternoon to increased mixing and dilution. Durant et al. (2010) presented 1-day measurements of pollutant mixing ratios, wind speed, and ambient temperature, along with traffic density. They observed an increase of pollutant levels before sunrise and a sharp decrease after sunrise. Hu et al. (2009) monitored pollutant mixing ratios, wind, and ambient temperature in the early morning period for 3 days. They found mixing ratios were much higher before sunrise even though traffic volume was lower than later during the daytime.

In this study we conducted measurements of gaseous pollutants, along with turbulent mixing conditions in the surface layer, continuously over 2 weeks from 16 to 31 July 2015 across Highway 401 in Toronto. Quantified pollutants discussed in the text include $\mathrm{CO}, \mathrm{NH}_{3}, \mathrm{O}_{3}$, formaldehyde ( $\mathrm{HCHO})$, hydrogen cyanide $(\mathrm{HCN})$, and methanol $\left(\mathrm{CH}_{3} \mathrm{OH}\right)$. $\mathrm{NH}_{3}, \mathrm{HCHO}$, and $\mathrm{HCN}$ have important implications to atmospheric chemistry and population health, and in situ measurements over busy highways have not been commonly reported for these (see details and references in the following sections). In addition, we used the proximity of a NAPS (National Air Pollution Surveillance) surface measurement sta- 
tion, which was located near the middle of the FTIR path next to the highway, to conduct an in-depth comparison of pollutants measured by both the path-integrating FTIR instrument and the in situ station $\left(\mathrm{CO}, \mathrm{O}_{3}\right.$, and $\left.\mathrm{NO}_{x}\right)$. To our knowledge, Grutter et al. (2005) presented the first of very few direct comparisons of this kind to be published. These data are then used to evaluate a research version of the GEM-MACH (Global Environmental Multiscale modelModelling Air quality and CHemistry) air quality forecast model (Moran et al., 2010; Gong et al., 2015; Makar et al., 2015a). Finally, highway-integrated emission rates of a few primary pollutants are estimated by a "top-down" approach using a backward Lagrangian stochastic dispersion model, and compared with previously published engine emission results scaled by traffic volume.

The objectives to be addressed with this analysis are (1) to evaluate the capabilities of the long-path FTIR spectroscopy for quantifying the mixing ratios of gaseous pollutants in a heavily polluted open urban traffic environment for a length of time sufficient to cover a range of environmental conditions (16 days); (2) to quantify gaseous-pollutant mixing ratios as a function of traffic volume and micrometeorological conditions; (3) to compare mixing ratios from these direct measurements to GEM-MACH model results; and (4) to evaluate the feasibility of deriving emission rate estimates from these measurements using an inverse dispersion model.

\section{Experimental}

\subsection{Long-path FTIR setup and analysis}

As shown in Fig. 1, the FTIR and scintillometer instruments were set up on the south side of Highway 401 at 125 Resources Road $\left(43.711^{\circ} \mathrm{N}, 79.543^{\circ} \mathrm{W}\right)$ in Toronto, Ontario, Canada. Our study was from 16 to 31 July 2015. The FTIR measurements were taken with a commercial openpath FTIR spectrometer (Open Path Air Monitoring System (OPS), Bruker, Germany). The infrared source is an aircooled globar. The emitted radiation is directed through the interferometer where it is modulated, travels along the measurement path across the highway, reaches a retroreflector array that reflects the radiation back, travels back across the highway, and enters a Stirling-cooled mercury cadmium telluride detector (bistatic configuration). The FTIR spectrometer was set up on the roof of a building, about $8 \mathrm{~m}$ above the ground, while the retroreflector array was mounted on a mast at $4 \mathrm{~m}$ above ground level north of Highway 401. The distance between the spectrometer and retroreflector array was $310 \mathrm{~m}$, resulting in a path length of $623.7 \mathrm{~m}$, which includes $3.7 \mathrm{~m}$ of internal reflections. The length of the path that was directly over the highway was $117 \mathrm{~m}$ (Fig. 1).

In this study, spectra were measured at a resolution of $0.5 \mathrm{~cm}^{-1}$ with 250 scans co-added to increase signal-to-noise ratio, resulting in roughly a 1-minute temporal resolution.
Before 23 July, 100 scan co-additions were used. At the beginning of the measurement period, a stray light spectrum was recorded by pointing the spectrometer away from the retroreflector. This stray light spectrum accounts for radiation back to the detector from reflections by internal parts inside the spectrometer, i.e., not from the retroreflector array, and was subtracted from all the measurement spectra before performing further analysis. Stray light affected retrieved final mixing ratios by $<3 \%$ in this study. Spectral ranges for retrieval analysis in the Bruker software, OPUS_RS, for each target gas were chosen based on prominent absorption features of the target gas and spectral windows as found in previous studies as shown in Table 1. Reference spectra were fitted to the measured spectra using nonlinear curve fitting methods within the chosen window.

For each gas of interest, a reference file was made including spectra of target and interference gases. High-resolution reference spectra at $296 \mathrm{~K}$ and $1013.25 \mathrm{hPa}$ were taken from the HITRAN database when available. For species not available in the HITRAN database, the reference spectra were taken from the PNNL database. Spectral ranges for fitting, interference gases, and detection limit based on Bruker's results for each pollutant retrieved in this work are listed in Table 1. Examples of measured spectra, model fit spectra in the optimum spectral ranges, and residuals are shown in Fig. S1 in the Supplement. Raw estimates of mixing ratios of gases of interest were retrieved assuming an ambient temperature of $296 \mathrm{~K}$ and air pressure of $1013.25 \mathrm{hPa}$. These values were then corrected for the actual temperature and pressure measured at the NAPS station using the ideal gas law.

The air temperature also has a secondary effect on the signature of the IR spectrum of individual gases. The population of the higher vibrational and rotational states increases as temperature increases. However, the sensitivity of temperature on those signatures depends on the individual gas and the range of temperature change. HITRAN and PNNL reference spectra at different temperatures are available for a limited number of species at 278, 298, and $323 \mathrm{~K}$ (Rothman et al., 1998, 2013; Sharpe et al., 2004; Johnson et al., 2010). Temperature-dependent reference files can be made in the OPUS_RS software to combine reference spectra at these three temperatures. To test the effect of temperature on the retrieved mixing ratio, spectra during the last 8 days of July were analyzed for $\mathrm{NH}_{3}, \mathrm{CH}_{4}, \mathrm{CO}$, and $\mathrm{CO}_{2}$ by using these temperature-dependent reference files. The maximum difference in retrieved mixing ratio for the $45^{\circ} \mathrm{C}$ range is $8.9 \%$ for $\mathrm{NH}_{3}, 4.2 \%$ for $\mathrm{CH}_{4}, 8.3 \%$ for $\mathrm{CO}$, and $4.1 \%$ for $\mathrm{CO}_{2}$. Based on this test, we estimate that using reference spectra at standard temperature and pressure contributed to an uncertainty of less than $10 \%$ in the final mixing-ratio results. Besides fitting errors and the effect of ambient temperature on reference spectrum, other environmental conditions may also contribute to uncertainties, such as interference from ambient water vapour. 


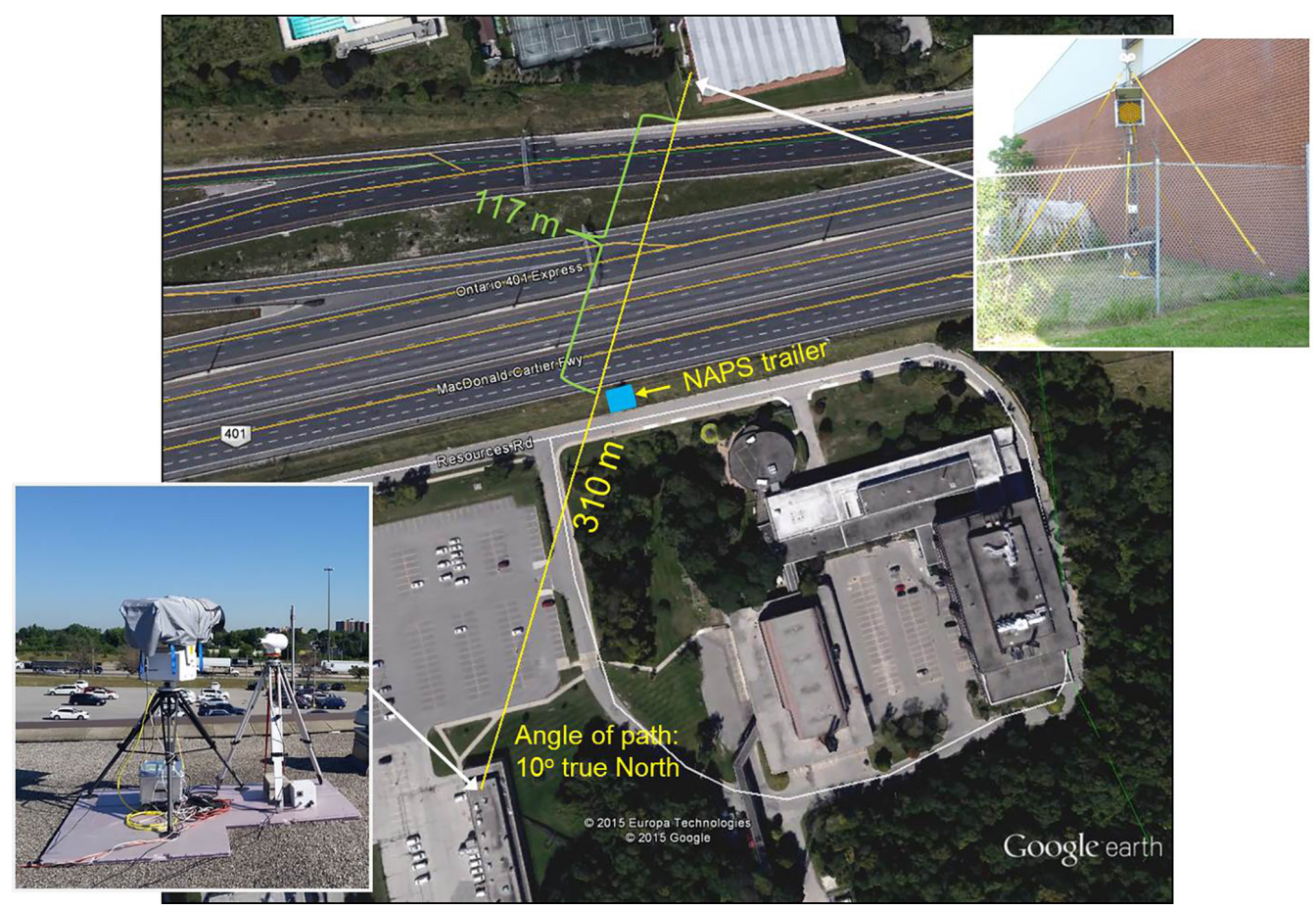

Figure 1. Setup of the FTIR spectrometer, scintillometer (see Sect. 2.2), and the NAPS trailer near Highway 401.

Table 1. Regions of long-path FTIR spectra used to retrieve mixing ratios of target gases in this study.

\begin{tabular}{|c|c|c|c|c|c|}
\hline Gases of interest & $\begin{array}{r}\text { Spectral region } \\
\text { fitted }\left(\mathrm{cm}^{-1}\right)\end{array}$ & $\begin{array}{l}\text { Interference gases } \\
\text { fitted }\end{array}$ & $\begin{array}{r}\text { Correlation } \\
\text { threshold }(r)^{\mathrm{a}}\end{array}$ & $\begin{array}{r}\text { Detection } \\
\operatorname{limit}(p p b)^{b}\end{array}$ & $\begin{array}{l}\text { Reference for spectral } \\
\text { region fitted }\left(\mathrm{cm}^{-1}\right)\end{array}$ \\
\hline CO (carbon monoxide) & $2142-2241$ & $\mathrm{H}_{2} \mathrm{O}, \mathrm{CO}_{2}, \mathrm{~N}_{2} \mathrm{O}$ & 0.7 & 0.8 & Smith et al. (2011) \\
\hline $\mathrm{CO}_{2}$ (carbon dioxide) & $2224-2255$ & $\mathrm{H}_{2} \mathrm{O}, \mathrm{N}_{2} \mathrm{O}, \mathrm{CO}$ & 0.97 & & Griffith (1996) \\
\hline $\mathrm{CH}_{4}$ (methane) & 2904-3024 & $\mathrm{H}_{2} \mathrm{O}$ & 0.95 & 0.8 & \\
\hline $\mathrm{O}_{3}$ (ozone) & $1040-1065$ & $\begin{array}{l}\mathrm{H}_{2} \mathrm{O}, \mathrm{NH}_{3}, \mathrm{CH}_{3} \mathrm{OH}, \\
\text { benzene, } \mathrm{HCHO}\end{array}$ & 0.4 & 4.9 & \\
\hline NO (nitrogen oxide) & $1893-1913$ & $\mathrm{H}_{2} \mathrm{O}$ & 0.1 & 6.5 & \\
\hline $\mathrm{NO}_{2}$ (nitrogen dioxide) & $1595-1607$ & $\mathrm{H}_{2} \mathrm{O}, \mathrm{NH}_{3}, \mathrm{CH}_{3} \mathrm{OH}$ & 0 & 8.2 & \\
\hline $\mathrm{SO}_{2}$ (sulfur dioxide) & $2465-2550$ & $\mathrm{H}_{2} \mathrm{O}, \mathrm{N}_{2} \mathrm{O}$ & 0.5 & 1.7 & \\
\hline $\mathrm{CH}_{3} \mathrm{OH}$ (methanol) & $980-1080$ & $\mathrm{H}_{2} \mathrm{O}, \mathrm{NH}_{3}, \mathrm{O}_{3}$ & 0.7 & 0.8 & \\
\hline $\mathrm{NH}_{3}$ (ammonia) & 910-990 & $\mathrm{H}_{2} \mathrm{O}$ & 0.7 & 0.8 & Smith at al. (2014) \\
\hline HCN (hydrogen cyanide) & $710-717$ & $\begin{array}{l}\mathrm{H}_{2} \mathrm{O}, \mathrm{N}_{2} \mathrm{O}, \mathrm{CO}_{2}, \\
\mathrm{C}_{2} \mathrm{H}_{2}, \mathrm{NH}_{3}, \mathrm{NO}_{2}\end{array}$ & 0.3 & 3.2 & Akagi et al. (2014) \\
\hline HCHO (formaldehyde) & $2740-2840$ & $\mathrm{H}_{2} \mathrm{O}, \mathrm{CO}_{2}, \mathrm{CH}_{4}$ & 0.3 & 1.7 & Akagi et al. (2014) \\
\hline $\mathrm{N}_{2} \mathrm{O}$ (nitrous oxide) & $2198-2223$ & $\mathrm{H}_{2} \mathrm{O}, \mathrm{CO}_{2}, \mathrm{CO}$ & 0.97 & 0.6 & Griffith (1996) \\
\hline $\mathrm{CH}_{3}(\mathrm{CO}) \mathrm{CH}_{3}$ (acetone) & 870-940 & $\begin{array}{l}\mathrm{H}_{2} \mathrm{O}, \mathrm{NH}_{3}, \mathrm{C}_{2} \mathrm{H}_{6}, \\
\mathrm{C}_{2} \mathrm{H}_{4}\end{array}$ & 0.3 & 2.5 & \\
\hline $\mathrm{C}_{2} \mathrm{H}_{2}$ (acetylene) & $680-780$ & $\mathrm{H}_{2} \mathrm{O}, \mathrm{CO}_{2}$ & 0.3 & 0.7 & \\
\hline $\mathrm{C}_{2} \mathrm{H}_{6}$ (ethane) & $800-850$ & $\mathrm{H}_{2} \mathrm{O}, \mathrm{CO}_{2}$ & 0 & 1.6 & \\
\hline $\mathrm{C}_{3} \mathrm{H}_{8}$ (propane) & 2860-2975 & $\begin{array}{l}\mathrm{H}_{2} \mathrm{O}, \mathrm{CH}_{4}, \mathrm{C}_{2} \mathrm{H}_{6}, \\
\mathrm{HCHO}, \mathrm{NO}_{2}\end{array}$ & 0 & 0.8 & \\
\hline
\end{tabular}

${ }^{a}$ Correlation thresholds are inputs for OPUS_RS used when retrieving the mixing ratios from FTIR spectra. When the correlation between the measured spectrum and reference spectrum in that spectral range is below this threshold, that pollutant is not "identified" and the mixing ratio will be reported as zero.

$\mathrm{b}$ Detection limit is calculated by converting $3 \sigma$ of the noise for measurements with a retroreflector distance of $225 \mathrm{~m}$ by Bruker to $3 \sigma$ of the noise with $310 \mathrm{~m}$ in our setup and then including the dependence of the signal intensity on the distance between the spectrometer and retroreflector, which is $12 \%$ in this case. 


\subsection{Scintillometer theory and setup}

Simultaneous long-path turbulence measurements were made using a boundary layer scintillometer (BLS 900, Scintec, Germany). The scintillometer receiver was set up next to the FTIR spectrometer, on the south side of Highway 401 (Fig. 1). The transmitter, with two disks of 924 LEDs emitting at $880 \mathrm{~nm}$, was set up on the north side of Highway 401 just above the FTIR retroreflector. The mean height of the scintillometer path was $8 \mathrm{~m}$ above ground level. In this study, the LEDs were operated in continuous mode. Radiation is directed onto the photodiodes in the receiver, which quantify the turbulence-induced fluctuations in the optical refractive index between the transmitter and receiver. The theory of scintillometer measurements and calculations are included in the Supplement Sect. S2. Sensible heat flux $(H)$, friction velocity $\left(u_{*}\right)$, and Obukhov length $(L)$ were calculated from scintillometer measurements at a 1 min resolution in this study.

$z / L$ (where $z$ is the height above the surface) is a surfacelayer scaling parameter describing the dynamic stability of the surface layer (Stull, 2003). Negative $z / L$ values indicate an unstable surface layer, while positive $z / L$ values indicate a stable surface layer. The closer the value of $z / L$ is to zero, the closer conditions are to neutral stability. In this work, $H$ and $z / L$ were used to determine the strength of turbulence and mixing in the surface layer (Fig. 2). Solar radiation data were taken from a York University weather station (http:// www.yorku.ca/pat/weatherStation/index.php) situated about $9 \mathrm{~km}$ northeast of our site. We used the downwelling short wavelength radiation data to quantify cloudiness during the study. During the 16-day measurement period, only 17 July had some rain, and all other days were mostly sunny.

\subsection{NAPS measurements}

The NAPS program aims to provide accurate and longterm air quality data with uniform standards across Canada by coordinating the data collection from existing air quality monitoring networks (Galarneau et al., 2016). The first NAPS measurements were conducted in 1972, focusing on $\mathrm{SO}_{2}$ and particulate matter. Currently, $\mathrm{SO}_{2}, \mathrm{CO}, \mathrm{NO}_{2}, \mathrm{O}_{3}$, and $\mathrm{PM}_{2.5}$ are continuously measured at more than 200 sites across Canada (Environment and Climate Change Canada, http://www.ec.gc.ca/ rnspa-naps/default.asp?lang=En\&n=8BA86647-1, last accessed 25 March 2017). The data shown in this study come from the NAPS trailer located right beside the FTIR path on the south edge of the Highway 401 (see Fig. 1). Pollutants monitored by this NAPS trailer include $\mathrm{CO}, \mathrm{NO}, \mathrm{NO}_{2}, \mathrm{O}_{3}$, $\mathrm{SO}_{2}$, and $\mathrm{PM}_{2.5}$ at 1-minute temporal resolution. The $\mathrm{CO}$ analyzer (model 48i TLE Enhanced Trace Level CO Analyzer, Thermo Fisher Scientific, USA) operates based on infrared absorption and gas filter correlation, the $\mathrm{NO}_{x}$ analyzer (model 42i Trace Level Nitrogen Oxide Analyzer, Thermo
Fisher Scientific, USA) on chemiluminescence, the $\mathrm{O}_{3}$ analyzer (model 49i, Thermo Fisher Scientific, USA) on UV absorption, the $\mathrm{SO}_{2}$ analyzer, (model 43i, Thermo Fisher Scientific, USA) on UV fluorescence, and the $\mathrm{PM}_{2.5}$ analyzer (model SHARP 5030, Thermo Fisher Scientific, USA) on light scattering and beta attenuation. Meteorological parameters, including air temperature, pressure, relative humidity, and wind speed and direction, were monitored using a WXT520 weather station (Vaisala, Finland).

\subsection{GEM-MACH model}

GEM-MACH is a chemical transport model embedded within the GEM (Global Environmental Multiscale) numerical weather forecast model of Environment and Climate Change Canada (ECCC) (Côté et al., 1998a, b). Meteorological conditions (Makar et al., 2015b) and air quality processes, including gas-phase, aqueous-phase, and heterogeneous chemistry and size-resolved aerosol processes, are included in GEM-MACH (Moran et al., 2010; Gong et al., 2015; Makar et al., 2015a). GEM-MACH is used operationally by ECCC for short-term air quality forecasting on a North American grid with $10 \mathrm{~km}$ horizontal grid spacing (Moran et al., 2014; Pavlovic et al., 2016). In this study, a research version of GEM-MACH simulated concentrations of pollutants with a horizontal grid-cell size of $2.5 \mathrm{~km}$ within a $40 \mathrm{~m}$ layer above ground level. Our measurement site was located within one model grid cell. Hourly outputs were obtained from GEM-MACH in this study.

GEM-MACH outputs instantaneous pollutant mixingratio fields once an hour, including $\mathrm{CO}, \mathrm{O}_{3}, \mathrm{NH}_{3}, \mathrm{HCHO}$, $\mathrm{NO}$, and $\mathrm{NO}_{2}$. The FTIR spectrometer and the NAPS measured mixing ratios once a minute. In order to compare model results and measurements for similar periods, GEM-MACH results were averaged over the two bracketing timestamps to get an estimate of the average mixing ratio of pollutants over each hour, while the measurements results were averaged every hour to match the temporal resolution of GEM-MACH results.

\subsection{WindTrax estimation of source emission rate from mixing-ratio measurements}

Various approaches have been developed to deduce source emission rates from pollutant concentrations, including inverse dispersion models (see Flesch et al., 2004). We used a backward Lagrangian stochastic (bLS) model (WindTrax, http://www.thunderbeachscientific.com; Flesch et al., 1995) to calculate the emission rate $Q$ through

$$
Q=\frac{\left(C-C_{\mathrm{b}}\right)}{(C / Q)_{\operatorname{sim}}},
$$

where $C$ is the concentration of a pollutant at the measurement site, $C_{\mathrm{b}}$ is the background concentration, and $(C / Q)_{\text {sim }}$ is the simulated ratio of concentration at the site to the emis- 


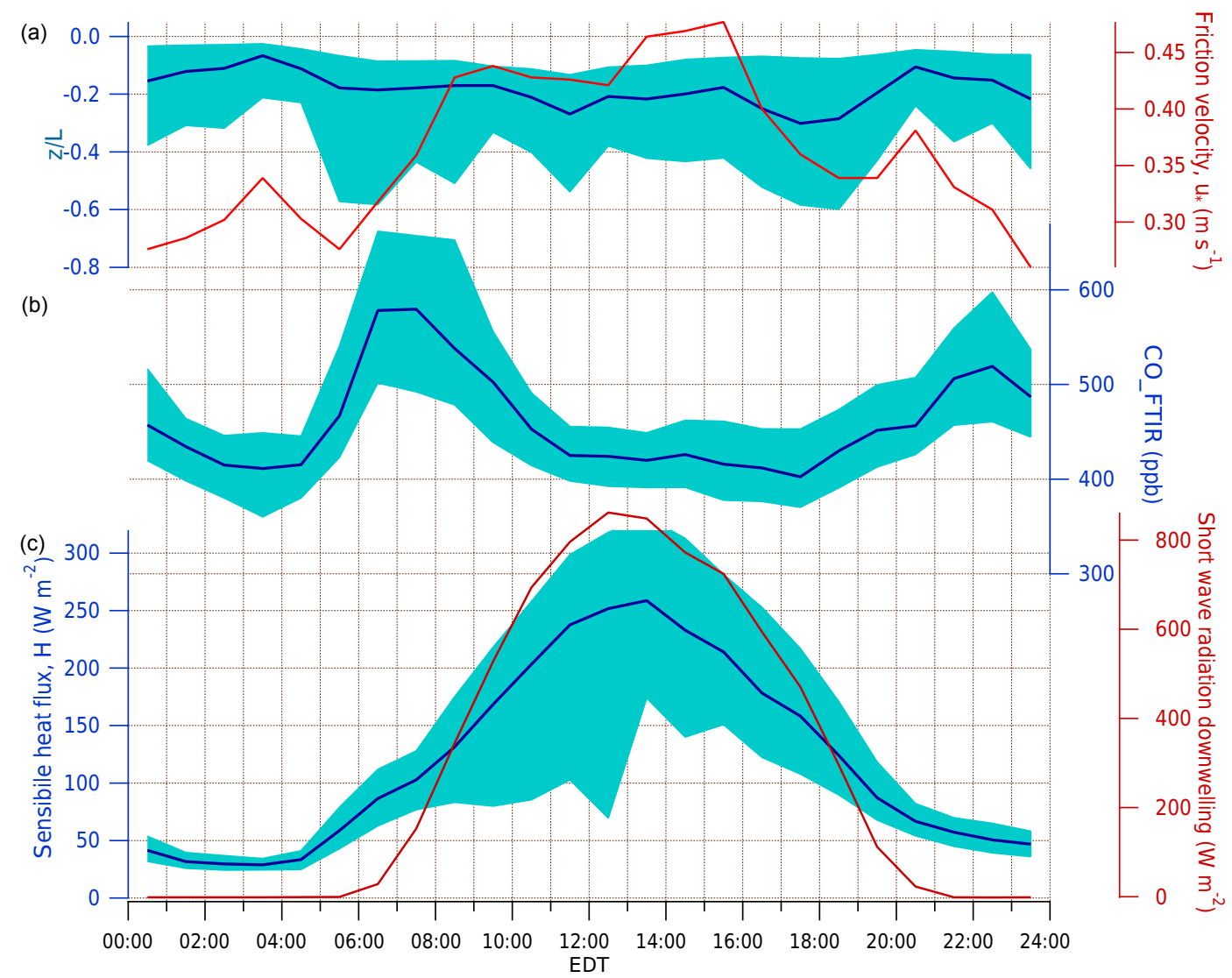

Figure 2. Average diurnal cycles (1-hour averages) of $z / L$ and $u_{*}$ (a), $\mathrm{CO}$ mixing ratio retrieved from the FTIR spectrometer (b), and sensible heat flux $H$ and downwelling shortwave radiation (c) for 16-31 July 2015. Lines represent the medians, and the shaded regions are the interquartile ranges for $z / L, \mathrm{CO}$, and $H$.

sion rate upwind. In the bLS model, a large number of virtual particles is released at the site, and individual upwind trajectories are calculated backward in time from the site. Then the fraction of trajectories that originate from the userpredetermined source area is calculated, which in turn factors into the calculation of $(C / Q)_{\text {sim. }}$. WindTrax can handle complex source-area shapes but not variations in topography. The micrometeorological condition inputs for the bLS model are $u_{*}$ (friction velocity) and $L$ (Obukhov length) obtained from the scintillometer measurements (Supplement Sect. S2) as well as wind and ambient temperature data from the NAPS trailer.

In this study, we used the mixing ratio of $\mathrm{CO}$ retrieved from FTIR spectroscopy to estimate the $\mathrm{CO}$ emission rate from the highway (a "top-down" approach). The estimated emission rates are then compared to the emission rates derived from traffic volumes combined with published emission factors of vehicle engines, i.e., a "bottom-up" approach (Sect. 3.7). These results will help evaluate the capability of deducing emission rates from our measurements.

\subsection{Traffic volume data}

Traffic volume data were provided by the Ontario Ministry of Transport, in units of vehicles per hour passing a point on Highway 401. Before 20 July, counts were available at the Islington Avenue intersection, about $700 \mathrm{~m}$ to the west of our site. However, after 20 July, data at Islington Avenue were not available, and we instead used traffic volume data at a nearby intersection to the east of our site at Avenue Road, which showed a linear relationship with traffic volumes at Islington Avenue. Therefore, the traffic volume data before 20 July were measured at the Islington Avenue intersection, while data after 20 July for the same location were estimated.

\section{Results and discussion}

\subsection{Micrometeorology}

During the study, the mean wind speed measured at the NAPS trailer was $2.5 \mathrm{~m} \mathrm{~s}^{-1}$, with a range from 0 to $9.9 \mathrm{~m} \mathrm{~s}^{-1}$ and quartiles of 1.3 and $3.3 \mathrm{~m} \mathrm{~s}^{-1}$. The mean friction velocity $u_{*}$ during the study was $0.40 \mathrm{~m} \mathrm{~s}^{-1}$, with a range from 
0.02 to $1.31 \mathrm{~m} \mathrm{~s}^{-1}$ and quartiles of 0.25 and $0.52 \mathrm{~m} \mathrm{~s}^{-1}$. The mean ambient temperature was $24^{\circ} \mathrm{C}$, with a range from 14 to $33{ }^{\circ} \mathrm{C}$.

In Toronto in late July, sunrise occurs at about 06:00 EDT (eastern daylight time; same time labels were used for the entire study), solar noon occurs at about 13:30, and sunset occurs at about 21:00. As shown in Fig. 2, sensible heat flux $H$ started to increase beginning at 06:00, reached its maximum in the early afternoon around 13:30, and then decreased to its minimum after 23:00. The downwelling shortwave solar radiation started to increase at $06: 30$ and reached a peak around 13:00. It is notable that $H$ remained positive throughout the night and started to increase before sunrise. We surmise that this is due to traffic providing a source of sensible heat and mechanical and convective turbulence, as well as slow release of heat from the pavement at night (Sailor and Lu, 2004; Khalifa et al., 2016). A rough estimation of 33 $\mathrm{W} \mathrm{m}^{-2}(56 \%$ of $H)$ at $05: 30$ (before the sunrise) was contributed by vehicles on the highway, based on the traffic volume, the ratio of energy loss from gasoline engine, and the typical fuel consumption of gasoline vehicles. Results of $z / L$ remained negative throughout the night, indicating that the surface layer was always unstable or neutral. $u_{*}$ also varied diurnally, with higher values from 08:00 to 21:00 and lower values during the night, which also suggests stronger turbulence in the daytime and is correlated with $H$. All of these measurements show that mixing and turbulence started to increase quickly after sunrise, reached a maximum in the early afternoon, and decreased to a minimum after 23:00.

\section{$3.2 \mathrm{CO}$}

\subsubsection{Comparison between FTIR spectroscopy, NAPS, and GEM-MACH}

$\mathrm{CO}$ is directly emitted by vehicles, and $\mathrm{CO}$ emission from vehicles and urban activities have been reported in previous studies (for example Chaney, 1983; Stedman, 1989; Stremme et al., 2013; Haugen and Bishop, 2017). Among those studies, Bradley et al. (2000) and Baldauf et al. (2008) measured CO from traffic by open-path FTIR spectroscopy. CO has also been used as a reference pollutant to determine emission factors of other primary pollutants by calculating concentration ratios of pollutants to $\mathrm{CO}$ (Warneke et al., 2007; Baker et al., 2008; Gentner et al., 2013). As shown in Fig. 3, many mixing-ratio peaks of $\mathrm{CO}$ from the FTIR spectrometer and the NAPS matched well, and mixing ratios generally correlated with each other (Fig. S2a), but these mixing ratios were also with a significant offset and amplitude difference when the wind came from the south (more detailed discussion in the next paragraph). The GEM-MACH simulation predictions and the measurements of $\mathrm{CO}$ mixing ratio agree well in general (Fig. 3). The GEM-MACH simulated most of the peak mixing ratios consistent with measurements.
A major contributing reason for the differences of $\mathrm{CO}$ mixing ratios between the FTIR spectrometer and the NAPS is that they were not sampling the exact same air, i.e., the measurements represented different footprints. The FTIR spectrometer measured the air along the path across and above the Highway 401, which always included some pollutants emitted from traffic. In contrast, NAPS numbers represented point measurements beside the south edge of the highway. Therefore, $\mathrm{CO}$ mixing ratios measured by the NAPS trailer were more dependent on the wind direction than mixing ratios obtained from the FTIR spectrometer. When the wind was from the south and towards the highway, the NAPS trailer was mostly blind to the highway; when the wind was from the north, it was immediately downwind it. Therefore, $\mathrm{CO}$ mixing ratios from the NAPS are expected to be lower than mixing ratios obtained from the FTIR spectrometer, when the wind is from the south and towards the highway.

The path-integrating approach of FTIR spectroscopy also has a dilution effect since a significant fraction of the path is not above the source (i.e., the highway). Therefore, the $\mathrm{CO}$ mixing ratios obtained from the FTIR spectrometer should be less than CO mixing ratios from NAPS, during the wind from highway towards the NAPS trailer. The polar plot in Fig. 4a clearly shows the dependence of the CO mixing-ratio difference between the FTIR spectrometer and the NAPS on wind direction. When the wind came from the north over the highway towards the NAPS trailer (above the dashed line), $\mathrm{CO}$ mixing ratios from the FTIR spectrometer were close to or lower than mixing ratios from the NAPS. When the wind was from the south and towards the trailer (below the dashed line), the CO mixing ratios from FTIR spectroscopy were higher than CO mixing ratios from NAPS.

Spatial incommensurability remains an issue when comparing gridded air quality model predictions with measurements. A GEM-MACH surface-level mixing ratio represents a mean value over a grid-cell volume that is $2.5 \mathrm{~km}$ by $2.5 \mathrm{~km}$ by $40 \mathrm{~m}$ in size whereas the FTIR measurements are averages over a line that is an order of magnitude shorter than the length of the side of GEM-MACH grid cell and the NAPS measurements correspond to values at a single point right at the south edge of the highway. In addition, the emissions considered by GEM-MACH for a particular grid cell include the contributions of all point, line, area, and volume sources contained within that grid cell, and the sum of these multiple sources is assumed to be distributed uniformly across the grid cell (see maps of grid cells Fig. S3). Thus, the artificial mixing and dilution of emissions within a model grid cell, subgrid-scale variations in wind direction, and the locations of emissions sources relative to measurement locations may impact the comparison between model results and measurements, particularly for primary pollutants.

To investigate the effect of wind direction on the difference of CO mixing ratios between from NAPS and GEM$\mathrm{MACH}$, the difference was plotted as a function of wind direction (Fig. 4b). GEM-MACH predictions were lower than 


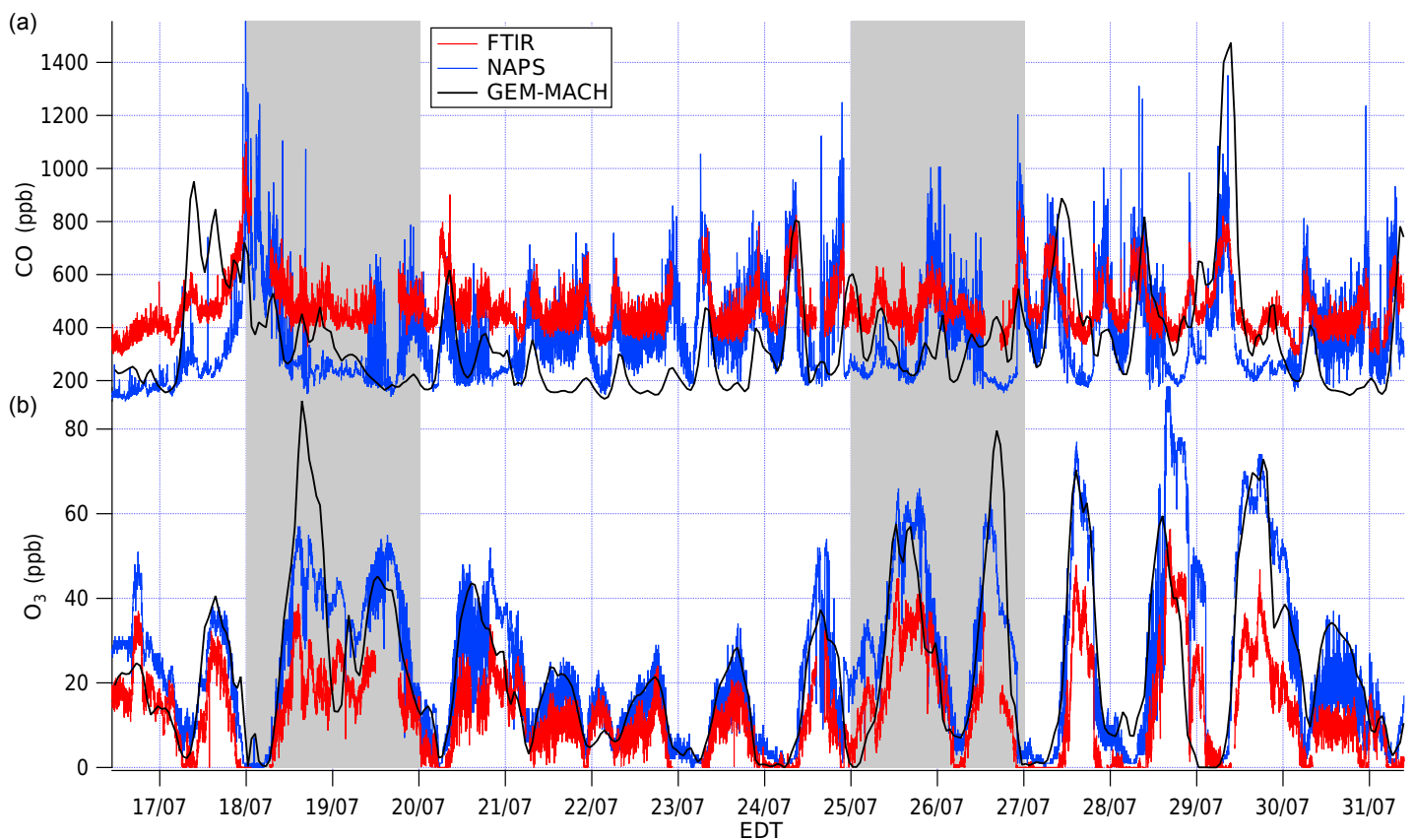

Figure 3. Time series of mixing ratios of $\mathrm{CO}$ (a) and $\mathrm{O}_{3}$ (b) for the full study period. The red traces are mixing ratios retrieved from the FTIR spectra. The blue traces are measurements from the NAPS station. The black traces are output from GEM-MACH. Grey shaded areas highlight the weekend periods.
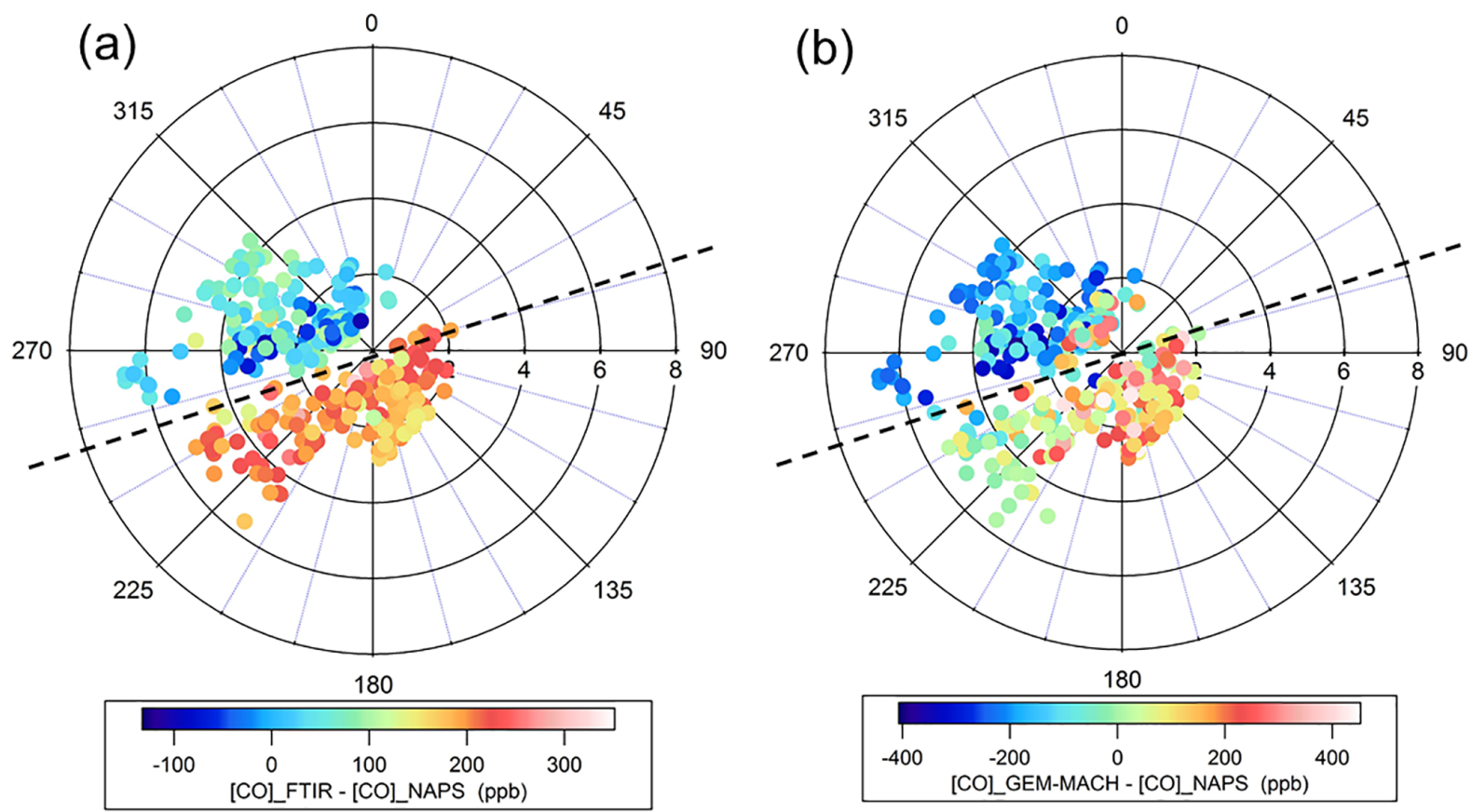

Figure 4. Polar plots of CO mixing-ratio difference between measurements from the FTIR spectrometer and NAPS (a) and between GEMMACH output and NAPS measurements (b). Azimuth angle represents wind direction (meteorological convention: $0^{\circ}=$ wind from north, $90^{\circ}=$ wind from east, etc.), and radius indicates wind speed $\left(\mathrm{m} \mathrm{s}^{-1}\right)$. The colour shows the CO mixing-ratio difference. The centre corresponds to the location of the NAPS trailer. The black dashed line shows the orientation of the highway: above this line, the wind came across the highway to the trailer. 
the NAPS measurements when the wind direction was from the highway towards the NAPS trailer (cold colours), while GEM-MACH predictions were greater than the NAPS measurements when the wind was from other directions (warm colours). A linear regression analysis of $\mathrm{CO}$ mixing ratios from GEM-MACH and NAPS stratified by wind direction is shown in Fig. S2b. The slope of the best-fit line when the wind was from the highway to the trailer was less than 1.0 and the mean bias was negative; for winds from other directions, the slope was greater than 1.0 and the mean bias was positive. These results are consistent with the above discussion about point-measurement representativeness vs. model grid-cell averages. When the wind was from the highway, $\mathrm{CO}$ measurements by the NAPS were directly influenced by the trailer's close proximity to heavy traffic emissions, a subgridscale emissions feature that could not be well represented by the air quality model.

The dependence of the difference of $\mathrm{CO}$ mixing ratios between FTIR spectroscopy and GEM_MACH on the wind direction was also studied. Figure S2c shows the difference of slopes in GEM-MACH vs. FTIR spectroscopy between conditions when wind from the highway and wind from other directions are smaller than the difference of slopes in GEMMACH vs. NAPS (Fig. S2b), indicating the sampling spatial difference is smaller when comparing $2.5 \mathrm{~km}$ gird cell in the model with path-integrated mixing ratio than when comparing $2.5 \mathrm{~km}$ gird cell in the model with a fixed point mixing ratio. From the polar plot of CO_model-CO_FTIR vs. wind direction in Fig. S4, it also can been seen that positive differences (warm colours) mainly occur when the wind was from other (non-highway) directions, and the dependence of CO_model-CO_FTIR on the wind direction is not as strong as CO_model-CO_NAPS (Fig. 4b).

\subsubsection{Average diurnal cycles}

During weekdays (Fig. 5), the minimum traffic volume was about 5000 vehicles $\mathrm{h}^{-1}$ between 02:00 and 05:00; traffic started to increase after 05:00 and reached a maximum 23800 vehicles $^{-1}$ from 07:00 to 08:00. After reaching the morning peak, traffic volume remained high through most of the day, starting to drop after 21:00. The CO mixing ratio on weekdays rapidly reached a peak between 06:00 and 08:00. $H$ and $u_{*}$ during this period were still low compared to the middle of the day (see Fig. 2), indicating that turbulence was weak compared to the afternoon. This suggests that the peaks of $\mathrm{CO}$ mixing ratio observe in the early morning were due to rapid increase and accumulation of emissions of $\mathrm{CO}$ while there was still little convection, before stronger mixing started later in the morning. Similar observations have been previously reported (Janhäll et al., 2006; Hu et al., 2009; Durant et al., 2010). In the afternoon on weekdays, when the traffic volume was still high, the $\mathrm{CO}$ mixing ratio dropped significantly, compared to early morning rush hour. Turbulence was strong at noon and in the afternoon, so emitted pollutants were diluted efficiently. Therefore $\mathrm{CO}$ mixing ratio in the afternoon was lower than in the morning despite similar traffic volumes. In the late evening (21:00 to 00:00), there was a secondary peak in mixing ratios of primary pollutants from traffic even as traffic volume started to drop, again due to diminished vertical mixing leading to accumulation in the surface layer after sunset (Gentner et al., 2009).

The average weekday diurnal cycles of $\mathrm{CO}$, traffic volume, and turbulence/mixing clearly show that turbulence and mixing played an important role on the mixing ratios of primary pollutants above the highway. On weekends, traffic volume increased more gradually during the morning until plateauing around 11:30 and on average remained high with about 21800 vehicles $\mathrm{h}^{-1}$ until after 22:00. The diurnal patterns of $\mathrm{CO}$ mixing ratio were flatter but with greater variability, compared to weekdays. The median $\mathrm{CO}$ mixing ratio on weekends was close to that on weekdays, except for the early morning period. These comparable CO levels for weekdays and weekends for similar traffic volumes suggest that traffic was the main emission source of $\mathrm{CO}$.

Ambient temperature may also affect emissions from vehicles and hence pollutant mixing ratios near traffic (U.S. EPA, 2010a; Rubin et al., 2006). However, since the range of ambient temperatures was small during the study period (from 15 to $32{ }^{\circ} \mathrm{C}$ ), the effect of temperature on the average diurnal cycle of $\mathrm{CO}$ mixing ratio was likely weak.

\section{$3.3 \quad \mathrm{NH}_{3}$}

$\mathrm{NH}_{3}$ can form secondary aerosols that are associated with negative health effects (Seinfeld and Pandis, 2006; Behera and Sharma, 2012; Liu et al., 2015) as well as radiative forcing impacts. According to the trend data for 2016 of the US Environmental Protection Agency (U.S. EPA, 2016), $2.4 \%$ of US national $\mathrm{NH}_{3}$ emissions are from vehicles which are more important sources in urban regions. After the threeway catalytic converter (TWC) was introduced to gasoline vehicles in 1981 and became used widely, $\mathrm{NH}_{3}$ (as a product formed in TWC from the reaction of NO with $\mathrm{CO}$ and $\mathrm{H}_{2} \mathrm{O}$ ) emissions from vehicles increased (Moeckli et al., 1996; Fraser and Cass, 1998; Kean et al., 2000). $\mathrm{NH}_{3}$ is also involved as a reagent in the reduction processes for NO in selective catalytic reduction converters (SCR) in diesel vehicles. Therefore, diesel vehicles could also contribute to $\mathrm{NH}_{3}$ emissions due to the aging of catalysts and overdoping of urea. However, they play only a minor role in $\mathrm{NH}_{3}$ traffic emissions compared to gasoline vehicles based on the emission inventory used by GEM-MACH over the Greater Toronto and Hamilton Area (projected 2015 inventory based on air quality modelling version of 2010 Canadian Air Pollutant Emission Inventory, Environment and Climate Change Canada, Ottawa, Ontario, November 2014, unpublished). $\mathrm{NH}_{3}$ is gaining importance as a pollutant from traffic due to the gaining use of emission control systems, but previous studies which directly measured $\mathrm{NH}_{3}$ mixing ratio from 


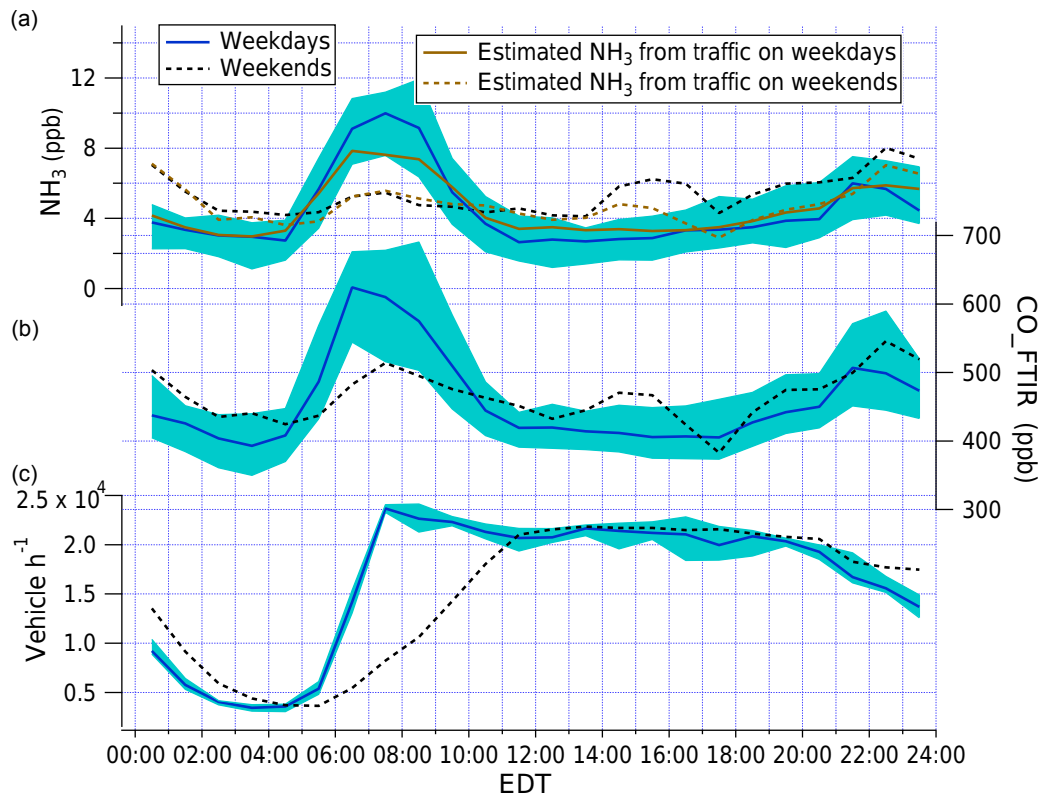

Figure 5. Average weekday and weekend diurnal cycles of mixing ratio of $\mathrm{NH}_{3}$ (a) and $\mathrm{CO}$ (b) from the FTIR spectrometer and traffic volume (c) for the 16-day study period. Blue solid lines are medians, and the shaded areas show the interquartile ranges for weekdays; black dashed lines are the medians for weekends. The brown solid line is an estimation of $\mathrm{NH}_{3}$ levels associated with traffic emissions on weekdays; the brown dashed line corresponds to weekends.

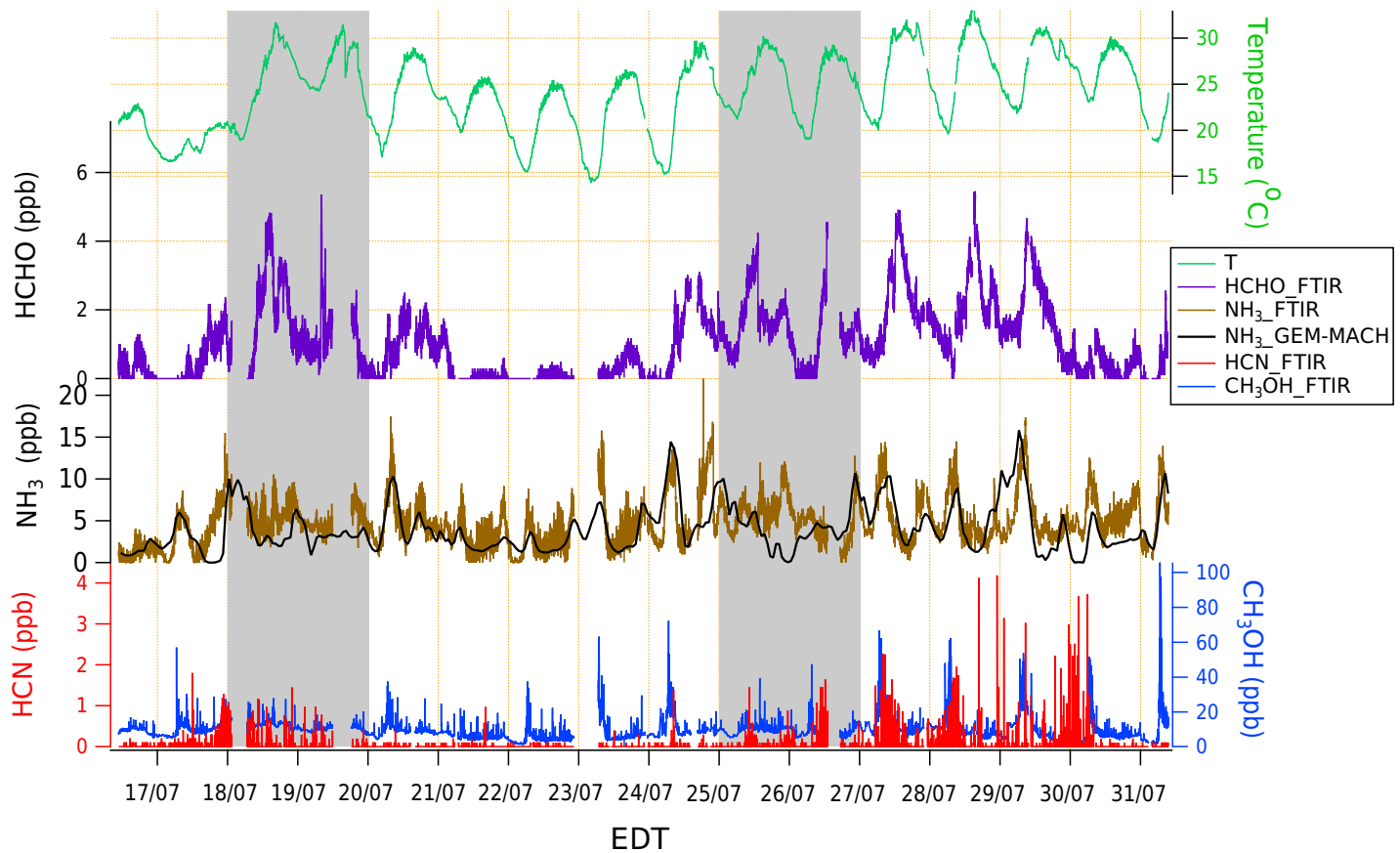

Figure 6. Time series of ambient temperature, mixing ratio of $\mathrm{HCHO}, \mathrm{NH}_{3}, \mathrm{HCN}$, and $\mathrm{CH}_{3} \mathrm{OH}$ for the 16-day study period. Grey shaded areas indicate the weekend periods.

traffic are rare. Elevated mixing ratios of $\mathrm{NH}_{3}$ between 0 and $23 \mathrm{ppb}$ were observed with the FTIR spectrometer in this study (Fig. 6). Baldauf et al. (2008) showed diurnal plots for traffic volume and mixing ratios of $\mathrm{NH}_{3}$ retrieved from open- path FTIR spectroscopy 20 and $300 \mathrm{~m}$ from a main road. The $\mathrm{NH}_{3}$ mixing ratio they reported was between 10 and $35 \mathrm{ppb}$, comparable to our results. 
Traffic emissions appear to be very important to $\mathrm{NH}_{3}$ in urban environments, although residential garbage collection (Reche et al., 2012), soil and fertilizers, biomass burning, natural ecosystems, sewage and landfill, and direct emissions by humans and animals could also contribute (Sutton et al., 2000). Yao et al. (2013) found a good linear correlation between mixing ratios of $\mathrm{NH}_{3}$ and $\mathrm{NO}$ during periods in the morning at the same site beside Highway 401. CO has been used as a common reference pollutant from vehicle emissions as discussed in Sect. 3.2.1, and studies have also used $\left[\mathrm{NH}_{3}\right]$ / [CO] ratio to correlate $\mathrm{NH}_{3}$ to traffic emissions (Perrino et al., 2002; Livingston et al., 2009). A linear correlation between emission factors of $\mathrm{CO}$ and $\mathrm{NH}_{3}$ was found in lightand medium-duty vehicles in the California South Coast Air Basin by Livingston et al. (2009). Perrino et al. (2002) found a linear relationship between mixing ratios of $\mathrm{NH}_{3}$ and $\mathrm{CO}$ at a traffic site in Rome. A linear relationship between $\mathrm{NH}_{3}$ and $\mathrm{CO}$ mixing ratios from the FTIR spectrometer over the whole period was also observed in this study (slope $=0.023$, $r^{2}=0.60$, Fig. S5). This linear relationship suggests that $\mathrm{NH}_{3}$ and $\mathrm{CO}$ shared a common source; in this case, a significant fraction (76\% during morning rush hour; see discussion in the next paragraph) of $\mathrm{NH}_{3}$ came from traffic. The slope of $0.023\left(\left[\mathrm{NH}_{3}\right] /[\mathrm{CO}]\right)$ is close to values previously reported (Livingston et al., 2009). $\mathrm{NH}_{3}$ emission factors from vehicles in the literature are in the range of 0 to $0.144 \mathrm{~g} \mathrm{~km}^{-1}$ depending on various factors such as fuel type, driving cycle, vehicle engine power, engine temperature, and catalyst aging (Durbin et al., 2002; Huai et al., 2003). Therefore, differences in slopes among studies are to be expected.

Average diurnal cycles of $\mathrm{NH}_{3}$ mixing ratios on weekdays and weekends are shown in Fig. 5. To estimate the $\mathrm{NH}_{3}$ due to traffic emissions, it was assumed that traffic emission was the only source of $\mathrm{CO}$ above background at this spatial scale and all $\mathrm{NH}_{3}$ from traffic emissions were correlated with CO. Thus, a background $\mathrm{CO}$ mixing ratio of $265 \mathrm{ppb}$ was subtracted from the retrieved $\mathrm{CO}$ mixing ratio and the result was regressed against $\mathrm{NH}_{3}$ mixing ratios, resulting in a traffic-related $\mathrm{NH}_{3}$ being estimated as $0.023 \times$ ([CO]_FTIR265) ppb. The $265 \mathrm{ppb} \mathrm{CO}$ background was the intercept of $\mathrm{CO}$ from the linear regression of $\mathrm{NH}_{3}$ with $\mathrm{CO}$. The resulting weekday and weekend diurnal cycles of the estimated $\mathrm{NH}_{3}$ mixing ratio due to traffic emissions are plotted in Fig. 5. During the morning rush hour and late at night on weekdays, traffic emissions contributed more to $\mathrm{NH}_{3}$ levels than during other times of day. On weekends, the diurnal variation of total $\mathrm{NH}_{3}$ was weaker, and estimated $\mathrm{NH}_{3}$ from traffic accounted for essentially all $\mathrm{NH}_{3}$ observed. Overall, there is no indication of a background offset of $\mathrm{NH}_{3}$, and most measured $\mathrm{NH}_{3}$ at this site can be accounted for by traffic emissions.

$\mathrm{NH}_{3}$ mixing ratio retrieved from FTIR spectroscopy also agreed well with GEM-MACH model simulations (Fig. 6). The analysis results of the traffic contribution to $\mathrm{NH}_{3}$ around the site based on the FTIR measurements are consistent with the GEM-MACH model $\mathrm{NH}_{3}$ input emissions, which show that the main source of $\mathrm{NH}_{3}$ at this location is vehicular (Fig. S3).

\section{4 $\mathrm{O}_{3}, \mathrm{NO}, \mathrm{NO}_{2}$, and $\mathrm{HCHO}$}

$\mathrm{O}_{3}$ is a secondary pollutant and is not emitted directly by vehicles. $\mathrm{NO}$ reacts with $\mathrm{O}_{3}$ forming $\mathrm{NO}_{2}$ on a timescale of a few minutes during the day. Photochemistry between VOCs and ambient oxidants produces $\mathrm{O}_{3}$, and $\mathrm{HCHO}$ is one of the products from these photochemical reactions. The chemistry of titration and photochemical production of $\mathrm{O}_{3}$ has been discussed previously in detail (Marr and Harley, 2002b; Fujita et al., 2003; Seinfeld and Pandis, 2006; Murphy et al., 2007). The time series of $\mathrm{O}_{3}$ mixing ratio from the FTIR spectrometer also agrees broadly with the NAPS $\mathrm{O}_{3}$ measurements (Fig. 3). However, the polar plot in Fig. 7a shows that $\mathrm{O}_{3}$ mixing ratios measured by the FTIR spectrometer and the NAPS were close when the wind was from the highway, whereas $\mathrm{O}_{3}$ from the FTIR spectrometer was much lower than $\mathrm{O}_{3}$ from the NAPS, when the wind was from other directions. These results can be explained by the titration of $\mathrm{O}_{3}$ over the highway by NO emissions from vehicles: when the wind is from the north, the $\mathrm{O}_{3}$ reaching the NAPS trailer has been titrated, but when the wind is from the south, $\mathrm{O}_{3}$ measured at the NAPS site is titrated over the highway downwind of the measurement point.

Mixing ratios of $\mathrm{NO}$ and $\mathrm{NO}_{2}$ can be retrieved from the FTIR spectra, but the correlation coefficients of fitting are less than 0.1 and estimated mixing ratios contain large offsets and biases, probably due to the strong interference from water vapour. Therefore, mixing ratios of $\mathrm{NO}$ and $\mathrm{NO}_{2}$ from the FTIR spectrometer are not shown here. The GEM-MACH simulations and NAPS measurements for $\mathrm{NO}$ and $\mathrm{NO}_{2}$ often do not agree well (Fig. 8). The disagreements can again be partially explained by the influence of wind direction. Like $\mathrm{CO}$ and $\mathrm{NH}_{3}$, $\mathrm{NO}$ is directly emitted from vehicles, but it reacts in the atmosphere much more quickly than $\mathrm{CO}$ or $\mathrm{NH}_{3}$. Polar plots for $\mathrm{NO}$ and $\mathrm{NO}_{2}$ (Fig. $7 \mathrm{~b}$ and c) show the effect of wind direction on the mixing-ratio differences between GEM-MACH results and NAPS measurements. When the wind blew from the NAPS trailer towards the highway, the difference was close to zero, but when the wind blew across the highway towards the trailer, GEM-MACH predictions were significantly lower than NAPS measurements. Similar to the CO comparison, the NAPS measurements were strongly influenced by traffic emissions when the wind came from highway compared to GEM-MACH. Note that GEM-MACH simulates mean pollutant mixing ratios within a $40 \mathrm{~m}$ layer and the inlet of the NAPS trailer was about $3 \mathrm{~m}$ above the ground. These different heights also contribute to the disagreement between measurements and model results. The $\mathrm{NO}_{x}\left(\mathrm{NO}_{x}=\mathrm{NO}+\mathrm{NO}_{2}\right)$ mixing ratio measured at the NAPS station on weekdays showed a similar average diurnal cycle (Fig. 9) to CO by the FTIR spectrometer, reaching a peak over $100 \mathrm{ppb}$ from 06:00 to 08:00 fol- 

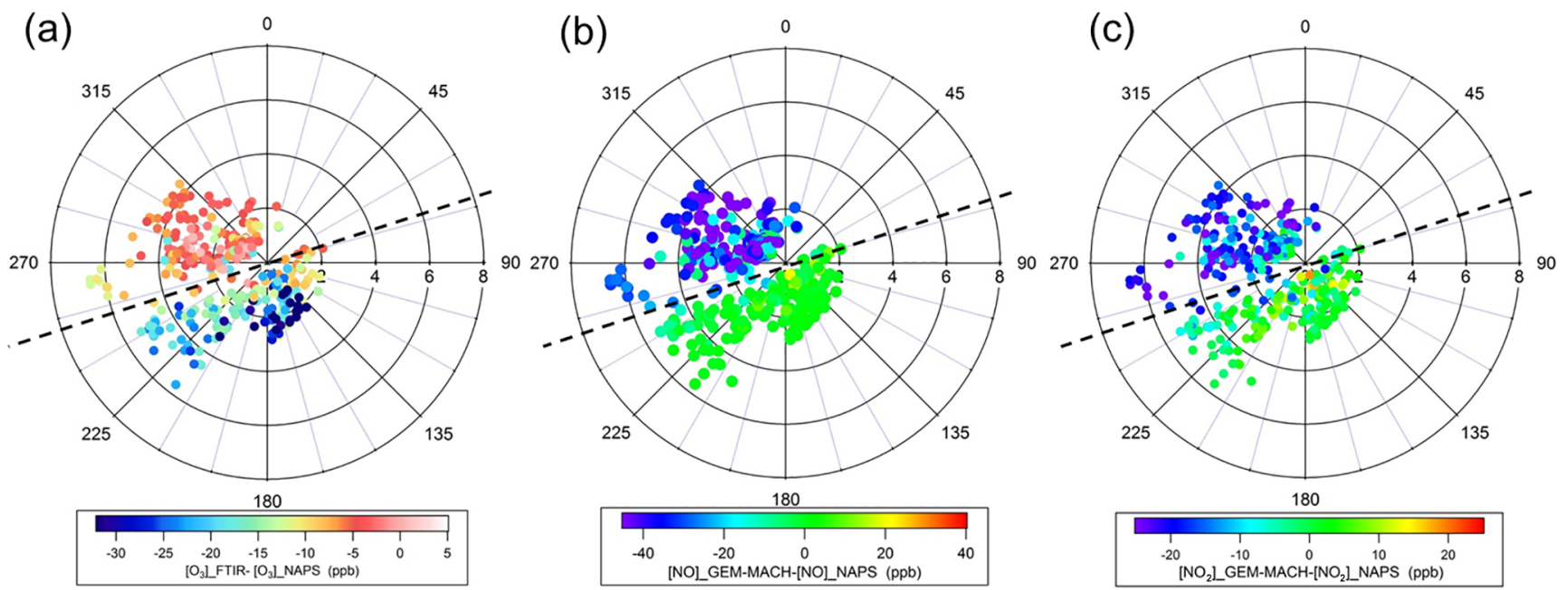

Figure 7. Polar plots of $\mathrm{O}_{3}$ mixing-ratio difference between measurements from the FTIR spectrometer and the NAPS (a); mixing-ratio difference between results from GEM-MACH predictions and hourly averaged measurements from NAPS for NO (b) and NO 2 (c). Azimuth angle represents wind direction (meteorological convention), and radius indicates wind speed $\left(\mathrm{m} \mathrm{s}^{-1}\right)$. The centre of each plot corresponds to the location of the NAPS trailer. The black dashed line shows the orientation of the highway: above this line, the wind came across the highway to the trailer.

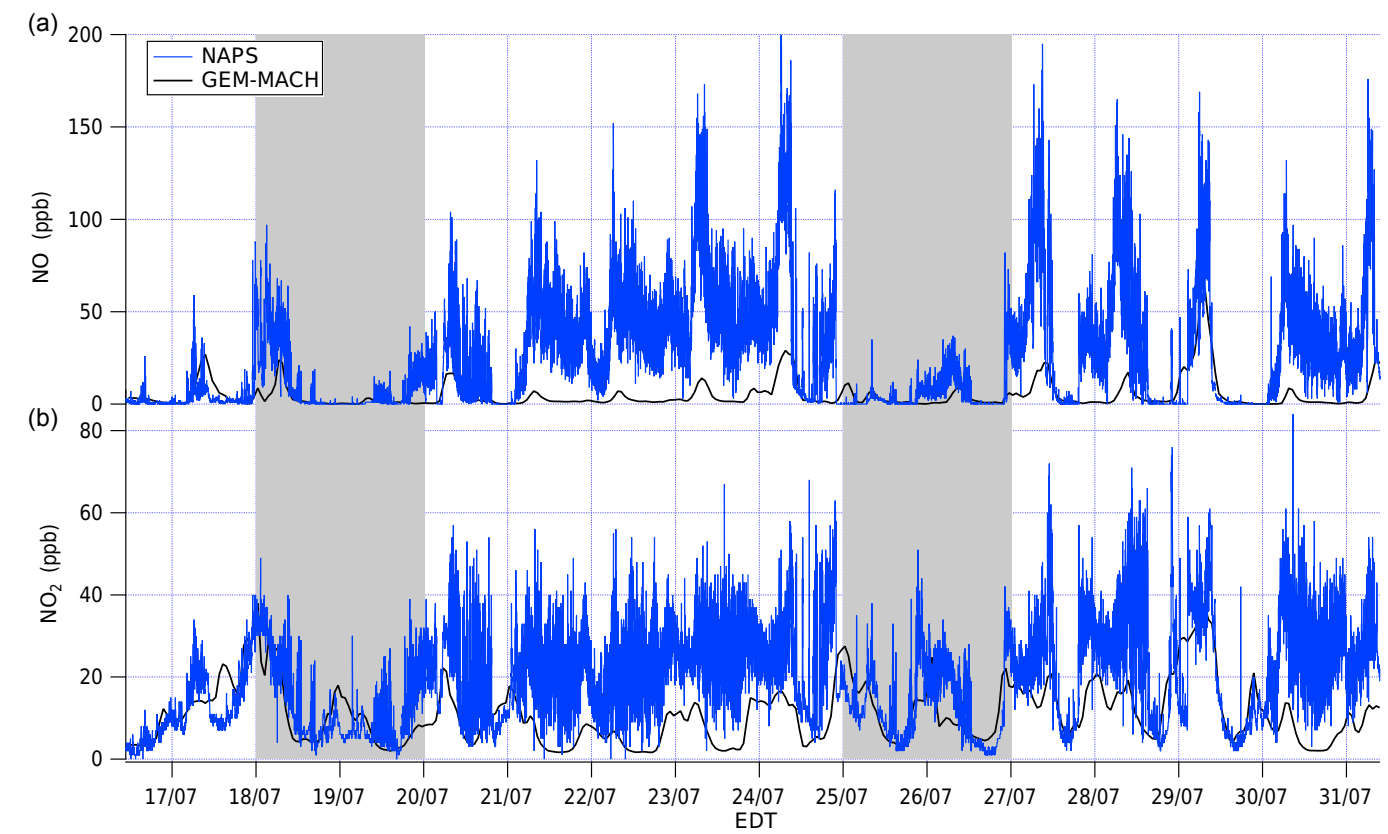

Figure 8. Time series of mixing ratios of $\mathrm{NO}$ (a) and $\mathrm{NO}_{2}$ (b). Grey shaded areas indicate the weekend periods.

lowed by significant decrease in the middle of the day and a secondary peak between 20:00 and 23:00. The diurnal cycle of $\mathrm{NO}_{x}$ on weekends with mixing ratios of $0-35 \mathrm{ppb}$ over the whole day, significantly lower than weekday $\mathrm{NO}_{x}$ levels, was also less variable. Reduced $\mathrm{NO}_{x}$ levels on weekends may have been due to fewer diesel vehicles operating on weekends; this pattern has been reported in studies in California (Marr and Harley, 2002a; Harley et al., 2005; Kim et al., 2016). Zhang et al. (2012) found that fewer diesel vehi- cles were observed on weekends on another major highway in the Toronto area. The annual sales of fuel used for onroad motor vehicles in Canada in 2015 were 42.6 billion L of gasoline and 18.0 billion L of diesel (Statistics Canada, 2016); i.e., a significant fraction of fuel burned is diesel. Therefore, lower diesel vehicle volumes on weekends may have contributed to different emissions of $\mathrm{NO}_{x}$ on Highway 401 near our site. The $\left[\mathrm{NO}_{x}\right] /[\mathrm{CO}]$ ratio also has been used to check the chemical conditions related to $\mathrm{O}_{3}$ produc- 


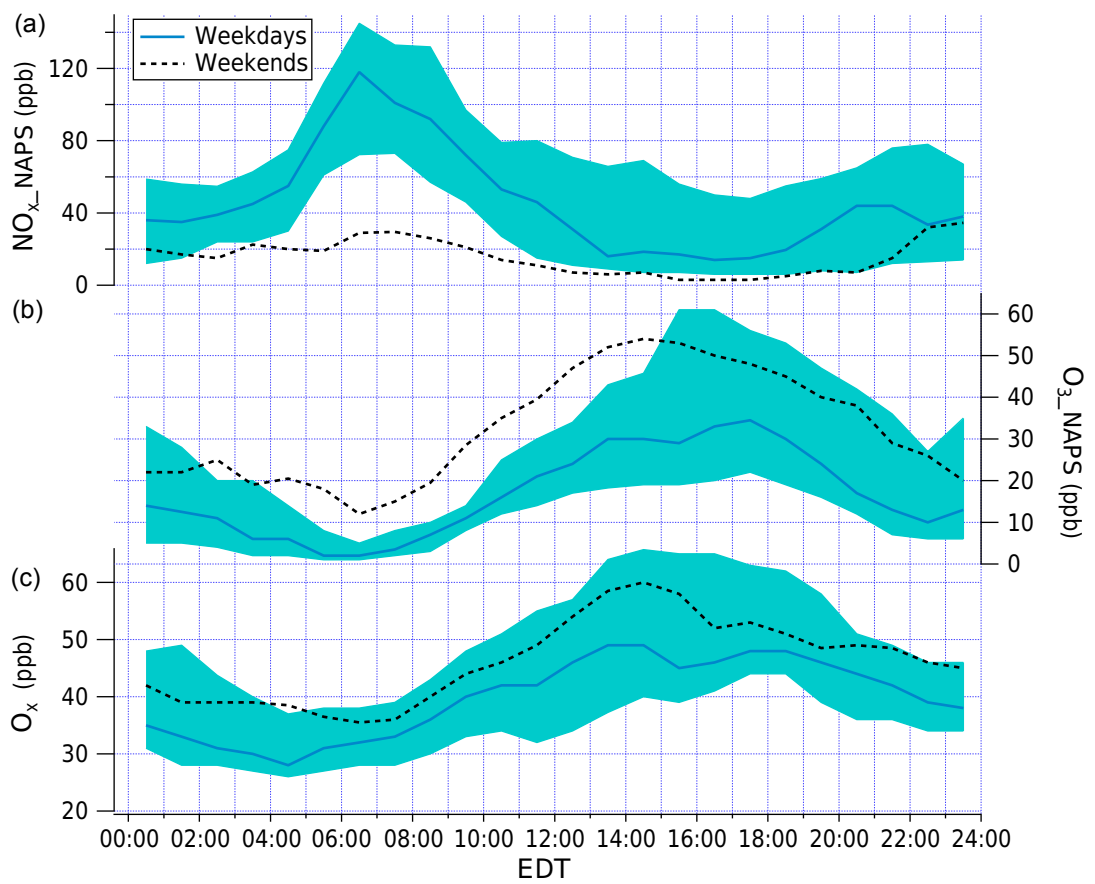

Figure 9. Average weekday and weekend diurnal cycles of mixing ratios of $\mathrm{NO}_{x}(\mathbf{a}), \mathrm{O}_{3}$ (b), and $\mathrm{O}_{x}$ (c) from the NAPS for the 16-day study period. Solid green lines are medians and the shaded areas are the interquartile ranges on weekdays; dashed black lines are medians on weekends.

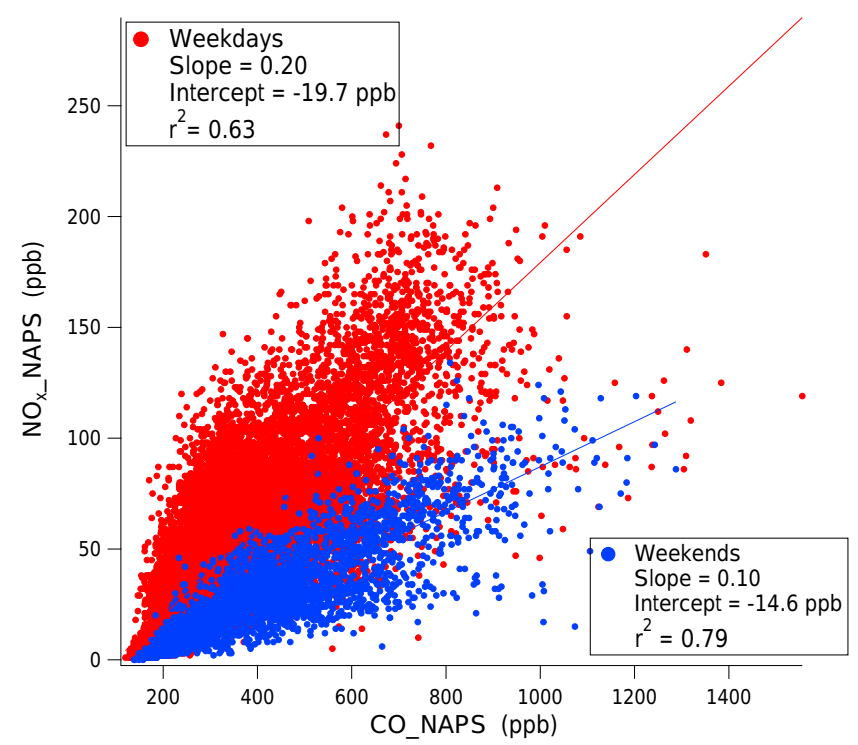

Figure 10. Scatterplot of $\mathrm{NO}_{x}$ vs. $\mathrm{CO}$ mixing ratios from the NAPS on weekdays (red) and weekends (blue). Lines are the linear regression results for weekdays (red) and weekends (blue).

tion. Figure 10 shows that the ratios in this study are 0.20 and 0.10 for weekdays and weekends, respectively. The lower ratio on weekends is likely due to reduced numbers of diesel vehicles, which is consistent with a previous study by Kim et al. (2016). Our $\left[\mathrm{NO}_{x}\right] /[\mathrm{CO}]$ ratios during both week- days and weekends are greater than their results $(0.11$ and 0.033 ), but our study only focused on near-surface observations over a short defined section of Highway 401 while their observations were at $1 \mathrm{~km}$ above the ground level with a bigger footprint which included off-road emissions and other local sources. Hassler et al. (2016) showed the trend of $\left[\mathrm{NO}_{x}\right] /[\mathrm{CO}]$ in the Los Angeles Basin, and the ratio is between 0.1 and 0.2 after 2010, which agrees well with our results. There are also some previous studies showing ratio of $[\mathrm{CO}] /\left[\mathrm{NO}_{x}\right]$ from regions near heavy traffic emission. Parrish et al. (2012) reported the slope of $[\mathrm{CO}]$ vs. $\left[\mathrm{NO}_{x}\right]$ was in the range of 6.3 to 18.9 for the measurement from 1987 to 1999. Wallace et al. (2012) reported the slope of [CO] vs. $\left[\mathrm{NO}_{x}\right]$ was 4.2 in the morning rush hours in 2009 . The slopes of $[\mathrm{CO}]$ vs. $\left[\mathrm{NO}_{x}\right]$ in this study are 3.14 and 7.75 for weekdays and weekends, respectively. Therefore our results on $\mathrm{NO}_{x}$ and $\mathrm{CO}$ are comparable with these previous studies.

Figure 9 also shows average weekday and weekend diurnal cycles for $\mathrm{O}_{3}$ measured at the NAPS station. One interesting feature is that the median diurnal $\mathrm{O}_{3}$ mixing ratios on weekends were consistently greater than on weekdays. Also, the diurnal cycles of $\mathrm{O}_{3}$ were inversely correlated with those for $\mathrm{NO}_{x}$. The low $\mathrm{O}_{3}$ mixing ratios in the mornings of weekdays can be explained by titration with high fresh emissions of NO from traffic, whereas the afternoon maximum is mainly due to production of $\mathrm{O}_{3}$ through increased levels of photochemistry with VOCs. The diurnal cycle of odd oxygen $\left(\mathrm{O}_{x}=\mathrm{O}_{3}+\mathrm{NO}_{2}\right)$ shown in Fig. 9 can be used 


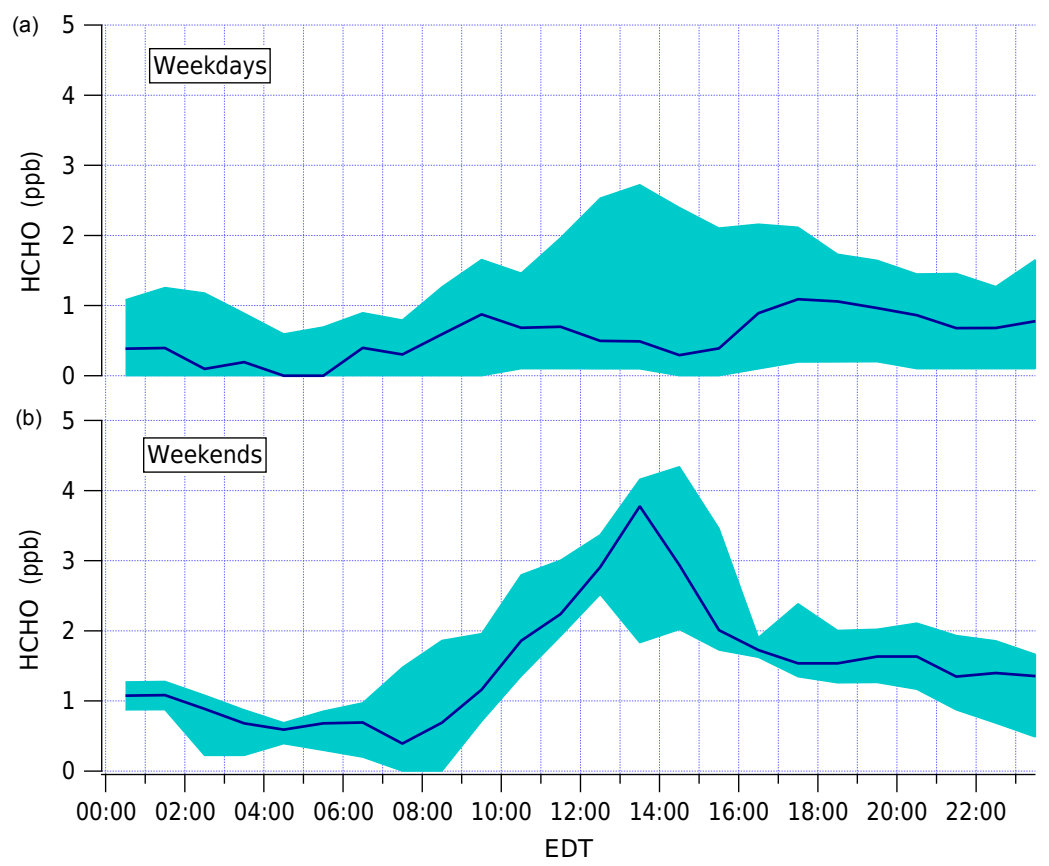

Figure 11. Average diurnal cycles of $\mathrm{HCHO}$ on weekdays (a) and on weekends (b) for the 16-day study period. Solid green lines are medians, and the shaded areas are the interquartile ranges.

to separate the contributions of titration and photochemistry with VOCs to $\mathrm{O}_{3}$ mixing ratios. Titration does not increase the sum of $\mathrm{O}_{3}$ and $\mathrm{NO}_{2}$, whereas photochemistry with VOCs does. Therefore, variations in $\mathrm{O}_{x}$ levels indicate that photochemistry with VOCs is important (Pollack et al., 2012). The average diurnal mixing ratios of $\mathrm{O}_{3}$ and $\mathrm{O}_{x}$ from NAPS measurements showing a maximum in the afternoon and being slightly higher on the weekends is also consistent with the average diurnal mixing ratios of HCHO showing a peak in the afternoon on weekends (Fig. 11). These diurnal results also suggest that the photochemistry with VOCs producing $\mathrm{NO}_{2}$ and $\mathrm{O}_{3}$ was important especially in the afternoon and on weekends. In addition, $\mathrm{O}_{x}$ levels peaked in the afternoon, also consistent with diurnal cycles of sunlight intensity (Fig. 2), which is a critical condition of photochemistry to produce $\mathrm{O}_{3}$. Other VOCs besides $\mathrm{HCHO}$ that were emitted by traffic and other local sources may also have contributed to the photochemical production of $\mathrm{O}_{3}$, but they were not quantified. Similar differences of $\mathrm{O}_{3}$ and $\mathrm{O}_{x}$ mixing ratios between weekdays and weekends were reported in the South Coast Air Basin (Pollack et al., 2012; Warneke et al., 2013). Temperature also affects $\mathrm{O}_{3}$ production, but given the great variation of $\mathrm{O}_{3}$ mixing ratio through the day, this was a secondary effect here based on box model calculations in the temperature range of our study (Coates et al., 2016).

To evaluate how representative the contrasts between weekends and weekdays based on this 16-day data set are compared to longer time frames, three summers of $\mathrm{O}_{3}$ measurements from a nearby NAPS station were extracted and analyzed (Supplement Sect. S3 and Fig. S7). Similar diurnal patterns and differences were observed in 2 of the 3 years, suggesting that the analysis presented above is representative of longer terms as well.

Time series of HCHO mixing ratios retrieved from the FTIR spectrometer shown in Fig. 6 were between 0 and $5 \mathrm{ppb}$. The average diurnal cycle of $\mathrm{HCHO}$ during weekends reached a peak in the early afternoon (shown in Fig. 11), which corresponded not to the average diurnal cycles of either traffic volume or primary pollutant $\mathrm{CO}$ but rather to the sunlight intensity (i.e., actinic radiation; see Fig. 2). This indicates that photochemistry of VOCs with oxidants was a dominant source (Stroud et al., 2016). The lifetime of HCHO in the atmosphere is on the scale of hours to days depending on the levels of ambient oxidants (Seinfeld and Pandis, 2006). Stroud et al. (2016) reported on levels of HCHO in Toronto and Egbert, Ontario, and source apportionment. Primary mobile emissions were found to contribute $\sim 12 \%$ of $\mathrm{HCHO}$ in Toronto. Previous research also showed that both light-duty and heavy-duty vehicles emit HCHO (Grosjean et al., 2001).

The correlation between $\mathrm{HCHO}$ mixing ratio and ambient temperature was moderate (Fig. S6a, $r^{2}=0.42$ ). HCHO levels were low for a few weekdays (22-24 July) with lower temperature as compared to the four warmer days sampled on the weekends. Therefore, the difference between the average weekday and weekend diurnal cycles shown in Fig. 11 may be due in part to sample size, and it is possible that other local HCHO emission sources which depend on the temper- 
ature may also have contributed to the HCHO observed, especially in the afternoons on weekends.

GEM-MACH simulations of $\mathrm{HCHO}$ mixing ratio are always greater than the FTIR measurements, but in the GEMMACH HCHO model species from the ADOM-II gas-phase chemistry mechanism is actually a lumped species that also includes isoprene oxidation products. Therefore, the GEM$\mathrm{MACH}$ results of $\mathrm{HCHO}$ are not shown here.

\subsection{HCN}

The mixing ratios of HCN retrieved from FTIR measurements were between 0 and 4 ppb (Fig. 6). Only on 28, 29, and 30 July was the HCN observed above its detection limit. HCN has severe adverse effects on human health, and chronic exposure to low cyanide can cause abnormal thyroid function and neurological problems (El Ghawabi et al., 1975; Blanc et al., 1985; Banerjee et al., 1997; U.S. EPA, 2010b). HCN has been reported previously in vehicle exhaust (Bradow and Stump, 1977; Keirns and Holt, 1978; Cadle et al., 1979; Urban and Garbe, 1979, 1980; Karlsson, 2004; Baum et al., 2007; Moussa et al., 2016). It may form over the catalytic converters in the vehicle emission control systems (Voorhoeve et al., 1975; Suárez and Löffler, 1986; Baum et al., 2007). A recent study for Toronto reported comparable HCN mixing-ratio values (Moussa et al., 2016). These HCN measurements contribute to the few studies reporting measurements of $\mathrm{HCN}$ mixing ratio beside a highway in urban ambient air.

\section{6 $\mathrm{CH}_{3} \mathrm{OH}$}

As shown in Fig. 6, mixing ratios of $\mathrm{CH}_{3} \mathrm{OH}$ from the FTIR spectrometer were between 2 and $20 \mathrm{ppb}$ most of the time, with some high spikes. Figure 12 presents the corresponding average weekday and weekend diurnal cycles of $\mathrm{CH}_{3} \mathrm{OH}$ for the study period. This plot shows the mixing ratio reached a peak (maximum of $20 \mathrm{ppb}$ at $07: 30$ ) from 07:00 to 09:00 on weekdays whereas there was no peak in the mornings on weekends. In addition, a linear relationship between $\left[\mathrm{CH}_{3} \mathrm{OH}\right]$ and $[\mathrm{CO}]$ was observed during the early morning rush hours on some weekdays (Table 2). These results suggest that at least a fraction of observed $\mathrm{CH}_{3} \mathrm{OH}$ was from traffic emissions. Observations of methanol associated with traffic have been reported in other studies. Rogers et al. (2006) reported $\mathrm{CH}_{3} \mathrm{OH}$ in the diluted pipeline exhaust of a mobile laboratory. $\mathrm{CH}_{3} \mathrm{OH}$ may also come from nonengine sources, such as windshield wiper fluid. Durant et al. (2010) measured gas and particle pollutants near Interstate 93 in Massachusetts. They reported $\mathrm{CH}_{3} \mathrm{OH}$ was above $20 \mathrm{ppb}$ at 07:20 50 m downwind of the highway, possibly with contributions from some other local sources. Reyes et al. (2006) reported vehicle emission of non-regulated pollutants, including methanol, by using local gasoline and driving conditions in Mexico City. Rantala et al. (2016) stud- ied urban VOC fluxes in urban Helsinki and found methanol fluxes were correlated with traffic and with CO fluxes, traffic could partially explain the observed methanol. Sahu and Saxena (2015) also reported $\mathrm{CH}_{3} \mathrm{OH}$ mixing ratios at Ahmedabad (an urban site in India), and both traffic emission and the transport from biomass burning and biogenic sources outside the city contributed to $\mathrm{CH}_{3} \mathrm{OH}$. The mixing ratio of $\mathrm{CH}_{3} \mathrm{OH}$ we observed did not correlate with ambient temperature (Fig. S6c), so there was no strong indication of biogenic sources.

\subsection{Estimation of emission factors}

To evaluate the feasibility of using measurement data from this study to estimate emission rates, we picked measurements for three days $(22,28$, and 29 July) from this study to use as inputs to a backward Lagrangian stochastic dispersion model (WindTrax, http://www.thunderbeachscientific.com/). 22 July was chosen, because the wind direction was steadily from northwest and a traffic jam occurred for added interest. 28 and 29 July were chosen, because they are two of the highest days for temperature and $\mathrm{O}_{3}$ during this project. The following were included as the inputs: $\mathrm{CO}$ mixing ratio from the FTIR spectrometer; background mixing ratio of $\mathrm{CO}$; winds and temperature from the NAPS trailer; and atmospheric stability $\left(u_{*}\right.$ and $\left.L\right)$ from the scintillometer. The surface roughness $\left(z_{0}\right)$ was set to $0.15 \mathrm{~m}$, the maximum allowed by WindTrax. The defined section of Highway 401, which was assumed to be the only $\mathrm{CO}$ source in the footprint, is about $1870 \mathrm{~m}$ long and $110 \mathrm{~m}$ wide. The FTIR path is roughly in the centre of the defined section. WindTrax was then used to estimate the emission rate of $\mathrm{CO}$ from this defined section. In the model, 50000 virtual particle trajectories were calculated upwind of the FTIR path with the given meteorological conditions (wind direction and temperature) and surface-layer turbulence ( $u_{*}$ and $L$ ), to determine what fraction of trajectories originated from the designated source area.

Over 3 days, 22, 28, and 29 July, CO emission rate estimates $\left(\mathrm{g} \mathrm{h}^{-1} \mathrm{~m}^{-2}\right)$ were calculated by WindTrax with a 1minute resolution for 10-minute periods, and the average estimates over those $10 \mathrm{~min}$ periods were calculated and shown as the markers in Fig. 13. The constant background used in WindTrax was $265 \mathrm{ppb}$, which was determined from the CO intercept of the linear regression analysis of $\mathrm{NH}_{3}$ with $\mathrm{CO}$ (see Sect. 3.3). The mixing ratio of changing background used in WindTrax was determined using a more dynamic definition of background based on wind direction. When the wind was from the south, the background was chosen as the NAPS measurement for 28 and 29 July. In the morning on 28 July when the wind was from the northwest, the background was chosen as $415 \mathrm{ppb}$, the minimum mixing ratio of that morning measured by the FTIR spectrometer. When the wind direction varied greatly, the background value of the previous hour was chosen. On 22 July, the wind was consis- 


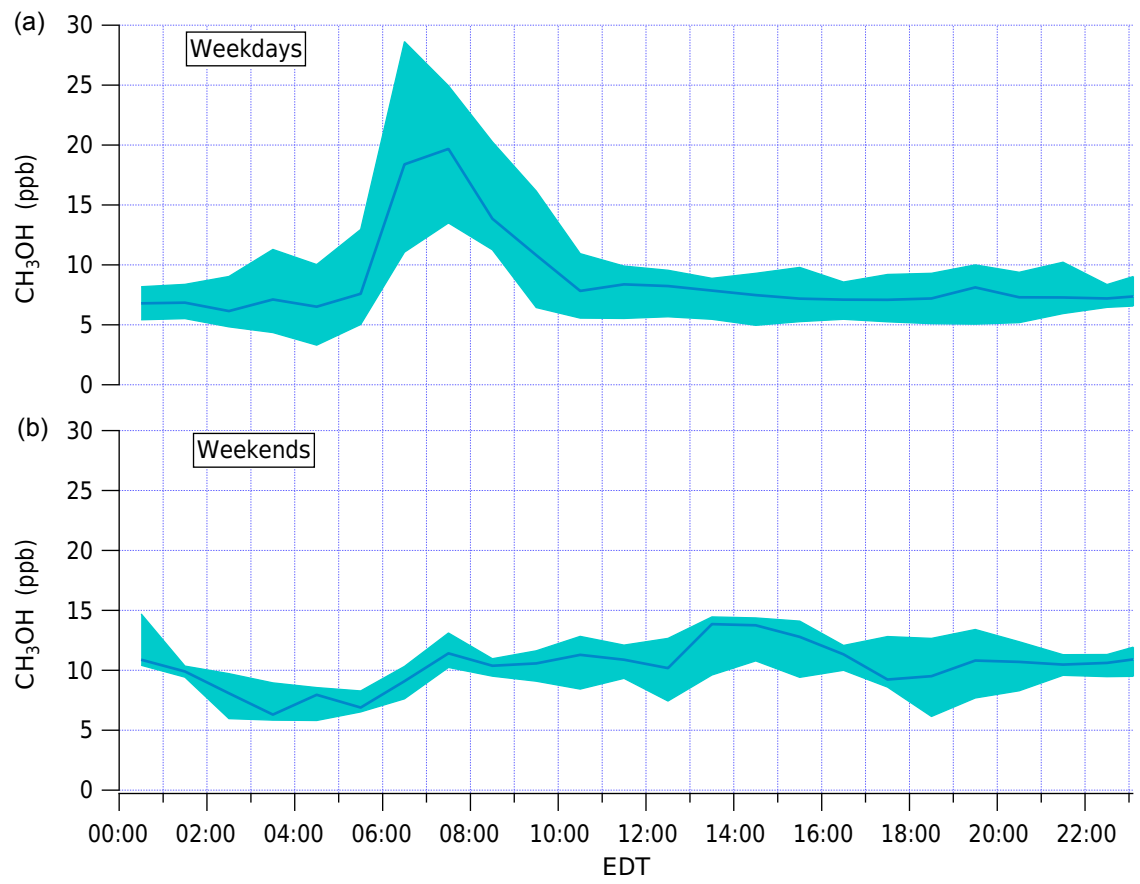

Figure 12. Average diurnal cycles of $\mathrm{CH}_{3} \mathrm{OH}$ mixing ratio on weekdays (a) and weekends (b) for the 16-day study period. Solid green lines are medians, and the shaded areas are the interquartile ranges.

Table 2. Pollutant emission rates.

\begin{tabular}{|c|c|c|c|c|}
\hline Pollutant & $\begin{array}{r}\text { [Pollutant }] /[\mathrm{CO}] \\
\quad\left(\text { ppbv ppbv }{ }^{-1}\right)\end{array}$ & $\begin{array}{l}\text { Emission rates } \\
\left(\mathrm{g} \mathrm{m}^{-2} \mathrm{~h}^{-1}\right)\end{array}$ & $\begin{array}{r}\text { Emission factors } \\
\text { (average) }\left(\mathrm{g} \mathrm{km}^{-1}\right)\end{array}$ & $\begin{array}{l}\text { Emission factors }\left(\mathrm{g} \mathrm{km}^{-1}\right) \\
\text { previously reported }\end{array}$ \\
\hline $\mathrm{CO}$ & 1 & $0-0.90$ & $0-6.97(2.6)$ & $\begin{array}{l}0.004-6.84 \text { (Liu and Frey, 2015) } \\
0.1-3.0 \text { (Moussa et al., 2016) }\end{array}$ \\
\hline $\mathrm{NH}_{3}$ & a 0.026 & $0-0.01$ & $0-0.11(0.04)$ & $\begin{array}{l}0-0.11 \text { (Durbin et al., 2002) } \\
0-0.144 \text { (Huai et al., 2003) } \\
0-0.26 \text { (Livingston et al., 2009) } \\
0.004-0.062 \text { (Suarez-Bertoa et } \\
\text { al., 2014) }\end{array}$ \\
\hline NO & $\mathrm{b}_{0.128}$ & $0-0.12$ & $0-0.96(0.36)$ & $0.008-1.26$ Frey et al. (2003) \\
\hline${ }^{\mathrm{c}} \mathrm{CH}_{3} \mathrm{OH}$ & ${ }^{\mathrm{c}} 0.051$ & $0-0.05$ & $0-0.41(0.15)$ & 0.0015-0.0067 Reyes et al. (2006) \\
\hline
\end{tabular}

${ }^{a}$ The ratio was found as the slope of the linear fit over the entire study period.

$\mathrm{b}$ The ratio was found as the average slope of the linear fits for the three early morning periods on 22, 28, and 29 July.

${ }^{\mathrm{c}}$ The ratio was found as the slope of the linear fit for 28 and 29 July.

tently from the northwest, and the minimum of $329 \mathrm{ppb}$ over the whole day from the FTIR spectrometer was chosen as the changing background.

Liu and Frey (2015) reported vehicular empirical cycle average emission factor for specific pollutant, vehicle, and driving cycle in grams per mile as well as average, minimum, and maximum values, based on empirical data measured between 2008 and 2013 in the Raleigh and Research Triangle Park area (North Carolina, USA) for 100 vehicles with a range of model years and accumulated mileage. We converted these results into $\mathrm{g} \mathrm{km}^{-1}$ emission factors ranging from 0.003 to
$5.1 \mathrm{~g} \mathrm{~km}^{-1}$ with an average value of $0.62 \mathrm{~g} \mathrm{~km}^{-1}$. They also reported simulated $\mathrm{CO}$ emission factors ranging from 0.004 to $6.87 \mathrm{~g} \mathrm{~km}^{-1}$ with an average value of $1.99 \mathrm{~g} \mathrm{~km}^{-1}$ by using the EPA's Motor Vehicle Emission Simulator (U.S. EPA, 2010a) emission factor model. Moussa et al. (2016) reported that emission factors of $\mathrm{CO}$ measured from several gasoline light-duty vehicles with different driving cycles ranged from 0.1 to $3.0 \mathrm{~g} \mathrm{~km}^{-1}$ with an average value of $0.9 \mathrm{~g} \mathrm{~km}^{-1}$.

Using emission factors from the MOVES model, traffic volume estimates, and the width of Highway 401 at the site, a "bottom-up" estimate of the emission rate $\left(\mathrm{g} \mathrm{h}^{-1} \mathrm{~m}^{-2}\right)$ 


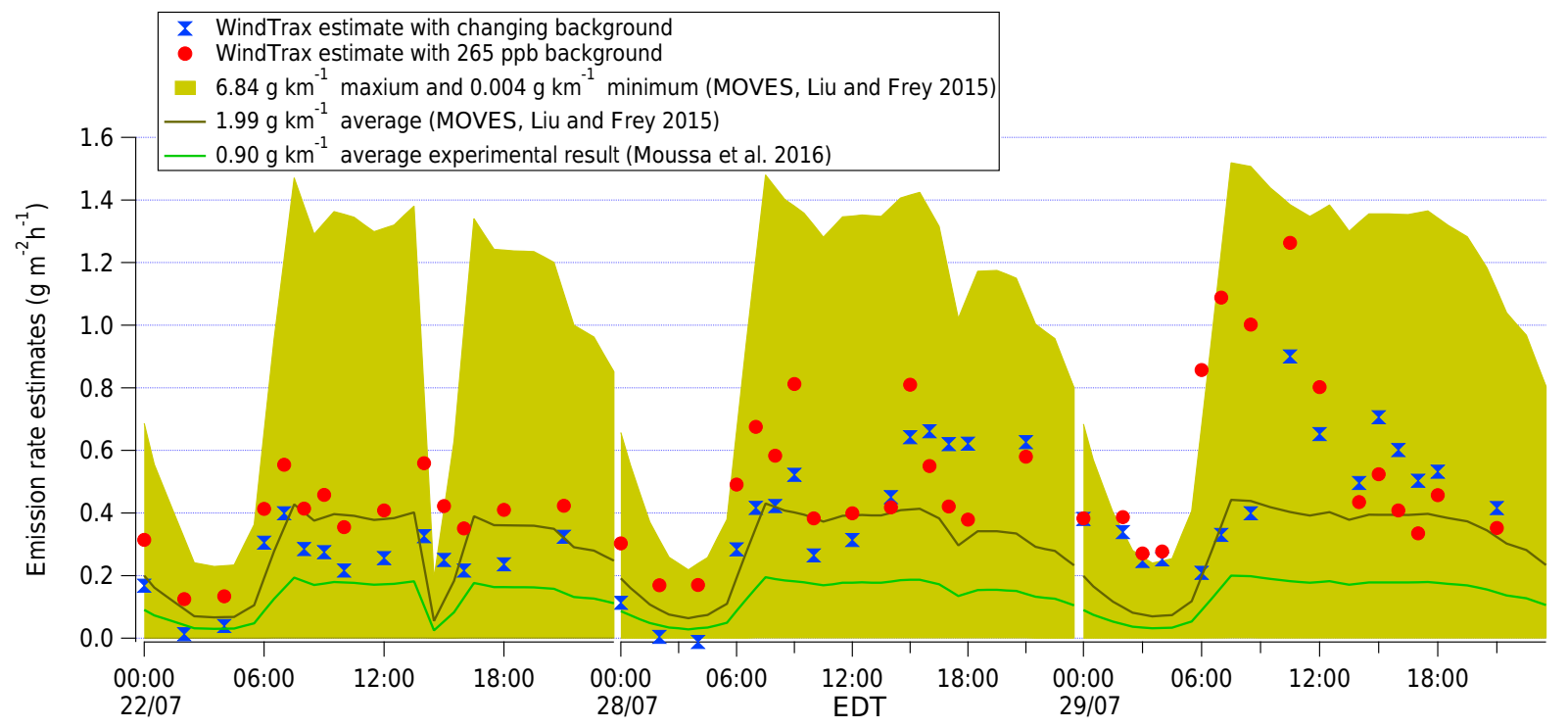

Figure 13. $\mathrm{CO}$ emission rate estimates over 3 days. Red dots are $\mathrm{CO}$ emission rates simulated by WindTrax using $\mathrm{CO}$ mixing ratios from the FTIR spectrometer and a constant CO background of $265 \mathrm{ppb}$ (see the text). Blue markers are CO emission rates simulated by the WindTrax using changing $\mathrm{CO}$ background values. The brown line is the $\mathrm{CO}$ emission rate estimated by using traffic volume estimates and emission factors from the average MOVES results in Liu and Frey (2015); the brown shade is the range of CO emission rates estimates obtained by using the maximum and minimum CO emission factor results from MOVES in Liu and Frey (2015). The green line is the CO emission rate simulated by using traffic volume estimates and the average $\mathrm{CO}$ emission factor from Moussa et al. (2016).

was calculated and compared to the dispersion model results (Fig. 13). There is a good agreement amongst the different approaches ( -140 to 460 and -110 to $70 \%$; see Fig. 13 and discussion below). On 22 July, the emission rate estimates from the WindTrax are close to the MOVES results. The MOVES estimates show a sharp drop between 14:00 and 15:30 due to decrease of traffic volume to $14 \%$ of at the value at 13:30. During this time, the emission rate estimates from the WindTrax do not fluctuate much. This result suggests that vehicle numbers passing by a fixed point may not be the best indicator of emissions since they do not account for the traffic speed: an extreme example would be a traffic jam with zero traffic flow but nonzero emissions. On 28 and 29 July, the estimates from the WindTrax are greater than the MOVES estimates. The difference between the emission rates estimated by using the WindTrax with changing background and by using 0.9 and $3.0 \mathrm{~g} \mathrm{~km}^{-1}$ from Moussa et al. (2016) is in the range of -140 to 460 and -110 to $70 \%$, respectively. These results suggest that WindTrax dispersion calculation results based on $\mathrm{CO}$ mixing-ratio measurements from the FTIR spectrometer and in situ micrometeorology are well within the range of estimates based on traffic volume and emission factors of various vehicles.

The input background mixing ratio assumed at each hour influences the emission rate estimates. Especially during the night around 00:00 to 06:00 when the wind was from north, it is difficult to determine the background mixing ratios of $\mathrm{CO}$, since no measurements were available upwind. Emis- sion rate estimates with both constant background and changing background were calculated to check the sensitivity of background mixing ratio on the emission rate estimates by the WindTrax. Our changing-background approach should be closer to reality, since conditions around the highway do change with time. Figure 13 shows that both estimates from the WindTrax using changing background and constant background agree in general with the bottom-up estimates, except for the period of the morning on 29 July when WindTrax estimates with the constant background are greater than the other estimates. The wind was from the south during this period and the assumed constant background of $265 \mathrm{ppb}$ was significantly lower than the NAPS measurements, resulting in an overestimate by the WindTrax. Beside the uncertainties in background mixing ratio, the variations in emission rate estimates are most likely due to changes in wind direction over short periods. When the wind direction changed quickly, the input wind direction used by the WindTrax may not be representative and hence may bias the calculated emission rate.

Emission rates of other primary pollutants from traffic can be determined by using the concentration ratios of these pollutants to $\mathrm{CO}$ and emission rate estimates of $\mathrm{CO}$, as mentioned in Sect. 3.2.1. We found that $\left[\mathrm{NH}_{3}\right]$ (as discussed in Sect. 3.3), $\left[\mathrm{CH}_{3} \mathrm{OH}\right]$, and early morning periods of [NO] had linear relationships with [CO]. With these ratios and emission rate estimates of $\mathrm{CO}$ obtained from the WindTrax (Fig. 13), the 10-minute average emission rate estimates of $\mathrm{NH}_{3}$, NO, and $\mathrm{CH}_{3} \mathrm{OH}$ were calculated. The minimum-to- 
maximum range and the average of these 10-minute average estimates are shown in Table 2. Emission factors in $\mathrm{g} \mathrm{km}^{-1}$ were calculated from WindTrax emission rates estimates by using the $110 \mathrm{~m}$ width of that section of highway and traffic volume to compare our estimates to previously reported emission factors.

The inputs of $u_{*}$ and $L$ from the scintillometer measurements also contain uncertainties. A realistic estimate of the uncertainty of $u_{*}$ is \pm 20 to $30 \%$ (Andreas, 1992). We conducted a sensitivity study by varying $u_{*}$ from 0.7 to 1.3 $u_{*(\mathrm{obs})}$ and $L$ from 2.20 to $0.34 L_{\text {(obs) }}$ corresponding to change of $u_{*}$ while keeping heat flux fixed, which resulted in emission rates from 0.69 to 1.37 times the original emission rate estimates. We also investigated the sensitivity of heat flux on emission rates estimates by varying $L$ from 0.5 to $2 L_{\text {(obs) }}$ with fixed $u_{*(\mathrm{obs})}$, which resulted in emission rates estimates in the range of 0.70 to 1.45 times the original emission rate estimates. Therefore, even with conservative uncertainty estimates about surface-layer stability, the calculated emission rates from the WindTrax are still within $45 \%$ of the bottom-up estimates.

WindTrax limits $z_{0}$ to a maximum value of $0.15 \mathrm{~m}$. However, the $z_{0}$ of the actual measurement site over the highway is around $0.6 \mathrm{~m}$ based on urban-scale meteorological model results for Toronto (Leroyer et al., 2016). This difference between the actual $z_{0}$ and the input $z_{0}$ used by WindTrax likely also contributes to the uncertainty of the emission rate estimates.

Better emission rate estimates might also be obtained if traffic information included vehicle types and vehicle speed. Speed and speed variation of different vehicle types are known to affect emission rates of $\mathrm{CO}$, hydrocarbon, and $\mathrm{NO}_{x}$ (Zhang et al., 2011), but consideration of these factors would have required more sophisticated traffic quantification.

\section{Summary and conclusions}

This study demonstrated the utility of combining long-path FTIR spectroscopy with micrometeorological measurements to identify and quantify pollutants emitted by moving traffic and to calculate emission rates in a representative realworld setting. We retrieved mixing ratios of eight air pollutants over Highway 401 in Toronto, Canada. Traffic emissions were shown to contribute quantifiable levels of $\mathrm{NH}_{3}$, $\mathrm{HCN}, \mathrm{HCHO}$, and $\mathrm{CH}_{3} \mathrm{OH}$ to the urban mix of pollutants. Of particular interest was the quantification of species such as $\mathrm{HCN}$, a toxic pollutant with severe health implications, and $\mathrm{NH}_{3}$, which may be gaining in importance due to the increasing use of catalytic converters which reduce vehicular $\mathrm{NO}_{x}$ emissions. Very few ambient data sets on these species from traffic-dominated environments are available in the published literature, and the methods described here can fill a significant gap.
Differences between weekdays and weekends in the average diurnal cycles of some of the pollutants mixing ratios ( $\mathrm{CO}, \mathrm{NO}_{x}, \mathrm{O}_{3}, \mathrm{NH}_{3}$, and $\left.\mathrm{HCHO}\right)$ were observed. The biggest differences are that on weekdays, the mixing ratios of primary pollutants from traffic, such as $\mathrm{CO}$ and $\mathrm{NH}_{3}$, showed an obvious peak in the early morning around 06:00 to 09:00, corresponding to the sharp increase of traffic volume during morning rush hour, while on weekends mixing ratios varied less throughout the day and no obvious peaks in the early morning were observed. Combined FTIR analysis and turbulence results clearly elucidated the role of turbulence in the build-up and dispersion of traffic emissions.

A comparison of the path-averaged FTIR spectroscopy with single-point NAPS measurements showed general agreement of the variations in mixing ratio but also differences due to the difference in measurement footprint. This comparison also uncovered some issues with offsets and amplitude differences between the FTIR and in situ analyzers that are likely due to pervasive $\mathrm{H}_{2} \mathrm{O}$ interference across the FTIR spectrum, especially for $\mathrm{NO}$ and $\mathrm{NO}_{2}$.

The modelled pollutant concentrations at the study site from a high-resolution version of the GEM-MACH air quality model agreed well in general with the measurements, especially for $\mathrm{CO}, \mathrm{O}_{3}$, and $\mathrm{NH}_{3}$. Given that the version of GEM-MACH considered here employed $2.5 \mathrm{~km}$ by $2.5 \mathrm{~km}$ grid cells, model results and measurement results are not expected to be directly comparable for all wind regimes, and comparisons can be better explained after separating wind directions.

Lastly, by combining mixing ratio with micrometeorological measurements and a simple dispersion model, we demonstrated the calculation of real-world, spatially representative vehicular emission rates using $\mathrm{CO}$ as an example and derived emission rates of $\mathrm{NH}_{3}, \mathrm{NO}$, and $\mathrm{CH}_{3} \mathrm{OH}$.

Data availability. The time series of retrieved mixing ratios from the FTIR, scintillometer turbulence measurements, and GEM-MACH outputs used in this study will be available at http://open.canada.ca/data/en/dataset/ f7ff59c9-80d2-4e63-932d-fa75793ed192. NAPS data are available at http://maps-cartes.ec.gc.ca/rnspa-naps/data.aspx?lang=en (National Air Pollution Surveillance Program of Government of Canada, 2017). Traffic volume data were obtained from the Ontario Ministry of Transportation, and information can be found at http://www.raqsb.mto.gov.on.ca/techpubs/TrafficVolumes.nsf/ tvweb?OpenForm\&Seq=6 (Ontario Ministry of Transportation, 2016).

The Supplement related to this article is available online at https://doi.org/10.5194/acp-17-14119-2017supplement. 
Competing interests. The authors declare that they have no conflict of interest.

Acknowledgements. We thank Andrew Sheppard, Andrew Elford, Roman Tiuliugenev, Raymon Atienza, and Rajananth Santhaneswaran (Environment and Climate Change Canada, ECCC) for their technical support; Richard Mittermeier (ECCC) for his help on the FTIR measurements and suggestions on FTIR analysis; the NAPS program (ECCC) for providing instruments to the NAPS trailer; Peter Maas (Bruker) for his suggestions on measuring and analyzing results using the OPUS_RS software; Aldona Wiacek and Li Li (Saint Mary's University) and David Griffith (University of Wollongong, Australia) for their suggestions on retrieving concentrations from FTIR spectroscopy; Terry Gillis (Pine Point Arena) for accommodating the retroreflector and LED array; Matthew Tuen (Ontario Ministry of Transportation) for providing the traffic volume data; Peter Taylor at the York University for providing meteorological data; Tak Chan and John Liggio (ECCC) for their comments on vehicle emissions; Sumi Wren and Jeff Brook for sharing results on their measurements of pollutants in urban Toronto; Andrea Darlington (ECCC) for her help on Igor program functions; and Chris Sioris (ECCC) for his review of the manuscript. We also acknowledge the developers of the OpenAir air quality analysis package for this remarkable tool (Carslaw and Ropkins, 2012; Carslaw, 2015).

Edited by: Jonathan Williams

Reviewed by: two anonymous referees

\section{References}

Akagi, S. K., Yokelson, R. J., Burling, I. R., Meinardi, S., Simpson, I., Blake, D. R., McMeeking, G. R., Sullivan, A., Lee, T., Kreidenweis, S., Urbanski, S., Reardon, J., Griffith, D. W. T., Johnson, T. J., and Weise, D. R.: Measurements of reactive trace gases and variable $\mathrm{O}_{3}$ formation rates in some South Carolina biomass burning plumes, Atmos. Chem. Phys., 13, 1141-1165, https://doi.org/10.5194/acp-13-1141-2013, 2013.

Akagi, S. K., Burling, I. R., Mendoza, A., Johnson, T. J., Cameron, M., Griffith, D. W. T., Paton-Walsh, C., Weise, D. R., Reardon, J., and Yokelson, R. J.: Field measurements of trace gases emitted by prescribed fires in southeastern US pine forests using an open-path FTIR system, Atmos. Chem. Phys., 14, 199-215, https://doi.org/10.5194/acp-14-199-2014, 2014.

Andreas, E. L.: Uncertainty in a path-averaged measurement of the friction velocity $u_{*}$, J. Appl. Meteorol., 31, 1312-1321, 1992.

Baker, A. K., Beyersdorf, A. J., Doezema, L. A., Katzenstein, A., Meinardi, S., Simpson, I. J., Blake, D. R., and Sherwood Rowland, F.: Measurements of nonmethane hydrocarbons in 28 United States cities, Atmos. Environ., 42, 170-182, https://doi.org/10.1016/j.atmosenv.2007.09.007, 2008.

Baldauf, R., Thoma, E., Hays, M., Shores, R., Kinsey, J., Gullett, B., Kimbrough, S., Isakov, V., Long, T., Snow, R., Khlystov, A., Weinstein, J., Chen, F.-L., Seila, R., Olson, D., Gilmour, I., Cho, S.-H., Watkins, N., Rowley, P., and Bang, J.: Traffic and meteorological impacts on near-road air quality: Summary of methods and trends from the Raleigh near-road study, J. Air Waste Man- age., 58, 865-878, https://doi.org/10.3155/1047-3289.58.7.865, 2008.

Banerjee, K. K., Bishayee, A., and Marimuthu, P.: Evaluation of cyanide exposure and its effect on thyroid function of workers in a cable industry, J. Occup. Environ. Med., 39, 258-260, https://doi.org/10.1097/00043764-199703000-00016, 1997.

Baum, M. M., Moss, J. A., Pastel, S. H., and Poskrebyshev, G. A.: Hydrogen cyanide exhaust emissions from inuse motor vehicles, Environ. Sci. Technol., 41, 857-862, https://doi.org/10.1021/es061402v, 2007.

Beckerman, B., Jerrett, M., Brook, J. R., Verma, D. K., Arain, M. A., and Finkelstein, M. M.: Correlation of nitrogen dioxide with other traffic pollutants near a major expressway, Atmos. Environ., 42, 275-290, https://doi.org/10.1016/j.atmosenv.2007.09.042, 2008.

Beckerman, B. S., Jerrett, M., Finkelstein, M., Kanaroglou, P., Brook, J. R., Arain, M. A., Sears, M. R., Stieb, D., Balmes, J., and Chapman, K.: The association between chronic exposure to traffic-related air pollution and ischemic heart disease, J. Toxicol. Env. Heal. A, 75, 402-411, https://doi.org/10.1080/15287394.2012.670899, 2012.

Behera, S. N. and Sharma, M.: Transformation of atmospheric ammonia and acid gases into components of $\mathrm{PM}_{2.5}$ : An environmental chamber study, Environ. Sci. Pollut. R., 19, 1187-1197, https://doi.org/10.1007/s11356-011-0635-9, 2012.

Bishop, G. A., McLaren, S. E., Stedman, D. H., Pierson, W. R., Zweidinger, R. B. and Ray, W. D.: Method comparisons of vehicle emissions measurements in the Fort McHenry and Tuscarora Mountain Tunnels, Atmos. Environ., 30, 2307-2316, https://doi.org/10.1016/1352-2310(95)00005-4, 1996.

Blanc, P., Hogan, M., Mallin, K., Hryhorczuk, D., Hessl, S., and Bernard, B.: Cyanide intoxication among silverreclaiming workers, J. Amer. Med. Assoc., 253, 367-371, https://doi.org/10.1001/jama.253.3.367, 1985.

Brachtl, M. V., Durant, J. L., Perez, C. P., Oviedo, J., Sempertegui, F., Naumova, E. N., and Griffiths, J. K.: Spatial and temporal variations and mobile source emissions of polycyclic aromatic hydrocarbons in Quito, Ecuador, Environ. Pollut., 157, 528-536, https://doi.org/10.1016/j.envpol.2008.09.041, 2009.

Bradley, K. S., Brooks, K. B., Hubbard, L. K., Popp, P. J., and Stedman, D. H.: Motor vehicle fleet emissions by OP-FTIR, Environ. Sci. Technol., 34, 897-899, https://doi.org/10.1021/es9909226, 2000.

Bradow, R. L. and Stump, F. D.: Unregulated emissions from three-way catalyst cars, International Automotive Engineering Congress and Exposition, 28 February4 March 1977, Detroit, MI, USA, SAE Tech. Pap., 770369, https://doi.org/10.4271/770369, 1977.

Brook, R. D.: Inhalation of fine particulate air pollution and ozone causes acute arterial vasoconstriction in healthy adults, Circulation, 105, 1534-1536, https://doi.org/10.1161/01.cir.0000013838.94747.64, 2002.

Brugge, D., Durant, J. L., and Rioux, C.: Near-highway pollutants in motor vehicle exhaust: A review of epidemiologic evidence of cardiac and pulmonary health risks, Environ. Health, 6, https://doi.org/10.1186/1476-069X-6-23, 2007.

Buckeridge, D. L., Glazier, R., Harvey, B. J., Escobar, M., Amrhein, C., and Frank, J.: Effect of motor vehicle emissions on respira- 
tory health in an urban area, Environ. Health Persp., 110, 293300, 2002.

Burling, I. R., Yokelson, R. J., Griffith, D. W. T., Johnson, T. J., Veres, P., Roberts, J. M., Warneke, C., Urbanski, S. P., Reardon, J., Weise, D. R., Hao, W. M., and de Gouw, J.: Laboratory measurements of trace gas emissions from biomass burning of fuel types from the southeastern and southwestern United States, Atmos. Chem. Phys., 10, 11115-11130, https://doi.org/10.5194/acp-10-11115-2010, 2010.

Cadle, S. H., Nebel, G. J., and Williams, R. L.: Measurements of unregulated emissions from general motors' light-duty vehicles, International Automotive Engineering Congress and Exposition, Detroit, MI, USA, 26 February-2 March 1979, SAE Tech. Pap., 790694, https://doi.org/10.4271/790694, 1979.

Carslaw, D. C.: The openair manual - open-source tools for analysing air pollution data. Manual for version 1.1-4, King's College London, available at: http://www.openair-project.org (last access: 23 November 2017), 2015.

Carslaw, D. C. and Ropkins, K.: openair - An R package for air quality data analysis, Environ. Modell. Softw., 27-28, 52-61, https://doi.org/10.1016/j.envsoft.2011.09.008, 2012.

Chaney, L. W.: The remote measurement of traffic generated carbon monoxide, J. Air Pollut. Control Assoc., 33, 220-222, https://doi.org/10.1080/00022470.1983.10465568, 1983.

Chen, H., Goldberg, M. S., Burnett, R. T., Jerrett, M., Wheeler, A. J., and Villeneuve, P. J.: Long-term exposure to traffic-related air pollution and cardiovascular mortality, Epidemiology, 24, 35-43, https://doi.org/10.1097/EDE.0b013e318276c005, 2013.

Chen, H., Kwong, J. C., Copes, R., Tu, K., Villeneuve, P. J., van Donkelaar, A., Hystad, P., Martin, R. V., Murray, B. J., Jessiman, B., Wilton, A. S., Kopp, A., and Burnett, R. T.: Living near major roads and the incidence of dementia, Parkinson's disease, and multiple sclerosis: A population-based cohort study, Lancet, 389, 718-726, https://doi.org/10.1016/S0140-6736(16)32399-6, 2017.

Coates, J., Mar, K. A., Ojha, N., and Butler, T. M.: The influence of temperature on ozone production under varying $\mathrm{NO}_{x}$ conditions - a modelling study, Atmos. Chem. Phys., 16, 11601-11615, https://doi.org/10.5194/acp-16-11601-2016, 2016.

Coleman, M. D., Render, S., Dimopoulos, C., Lilley, A., Robinson, R. A., Smith, T. O. M., Camm, R., and Standring, R.: Testing equivalency of an alternative method based on portable FTIR to the European Standard Reference Methods for monitoring emissions to air of $\mathrm{CO}, \mathrm{NO}_{x}, \mathrm{SO}_{2}$, $\mathrm{HCl}$, and $\mathrm{H}_{2} \mathrm{O}$, J. Air Waste Manage., 65, 1011-1019, https://doi.org/10.1080/10962247.2015.1058868, 2015.

Côté, J., Desmarais, J. G., Gravel, S., Méthot, A., Patoine, A., Roch, M., and Staniforth, A.: The operational CMC-MRB global environmental multiscale (GEM) model. Part II: Results, Mon. Weather Rev., 126, 1397-1418, 1998a.

Côté, J., Gravel, S., Méthot, A., Patoine, A., Roch, M., and Staniforth, A.: The operational CMC-MRB global environmental multiscale (GEM) model. Part I: Design considerations and formulation, Mon. Weather Rev., 126, 1373-1395, 1998b.

Durant, J. L., Ash, C. A., Wood, E. C., Herndon, S. C., Jayne, J. T., Knighton, W. B., Canagaratna, M. R., Trull, J. B., Brugge, D., Zamore, W., and Kolb, C. E.: Short-term variation in nearhighway air pollutant gradients on a winter morning, Atmos.
Chem. Phys., 10, 8341-8352, https://doi.org/10.5194/acp-108341-2010, 2010.

Durbin, T. D., Wilson, R. D., Norbeck, J. M., Miller, J. W., Huai, T., and Rhee, S. H.: Estimates of the emission rates of ammonia from light-duty vehicles using standard chassis dynamometer test cycles, Atmos. Environ., 36, 1475-1482, https://doi.org/10.1016/S1352-2310(01)00583-0, 2002.

El Ghawabi, S. H., Gaafar, M. A., El-Saharti, A. A., Ahmed, S. H., Malash, K. K., and Fares, R.: Chronic cyanide exposure: a clinical, radioisotope and laboratory study, Brit. J. Ind. Med., 32, 215-219, 1975.

Flesch, T. K., Wilson, J. D., and Yee, E.: Backward-time Lagrangian stochastic dispersion models and their application to estimate gaseous emissions, J. Appl. Meteorol., 34, 1320-1332, 1995.

Flesch, T. K., Wilson, J. D., Harper, L. A., Crenna, B. P., and Sharpe, R. R.: Deducing ground-to-air emissions from observed trace gas concentrations: A field trial, J. Appl. Meteorol., 43, 487-502, 2004.

Fraser, M. P. and Cass, G. R.: Detection of excess ammonia emissions from in-use vehicles and the implications for fine particle control, Environ. Sci. Technol., 32, 1053-1057, https://doi.org/10.1021/es970382h, 1998.

Frey, H. C., Unal, A., Rouphail, N. M., and Colyar, J. D.: On-road measurement of vehicle tailpipe emissions using a portable instrument, J. Air Waste Manage., 53, 992-1002, https://doi.org/10.1080/10473289.2003.10466245, 2003.

Fujita, E. M., Stockwell, W. R., Campbell, D. E., Keislar, R. E., and Lawson, D. R.: Evolution of the magnitude and spatial extent of the weekend ozone effect in California's South Coast Air Basin, 1981-2000, J. Air Waste Manage., 53, 802-815, https://doi.org/10.1080/10473289.2003.10466225, 2003.

Galarneau, E., Wang, D., Dabek-Zlotorzynska, E., Siu, M., Celo, V., Tardif, M., Harnish, D., and Jiang, Y.: Air toxics in Canada measured by the National Air Pollution Surveillance (NAPS) program and their relation to ambient air quality guidelines, J. Air Waste Manage., 66, 184-200, https://doi.org/10.1080/10962247.2015.1096863, 2016.

Gentner, D. R., Harley, R. A., Miller, A. M., and Goldstein, A. H.: Diurnal and seasonal variability of gasoline-related volatile organic compound emissions in Riverside, California, Environ. Sci. Technol., 43, 4247-4252, https://doi.org/10.1021/es9006228, 2009.

Gentner, D. R., Isaacman, G., Worton, D. R., Chan, A. W. H., Dallmann, T. R., Davis, L., Liu, S., Day, D. A., Russell, L. M., Wilson, K. R., Weber, R., Guha, A., Harley, R. A., and Goldstein, A. H.: Elucidating secondary organic aerosol from diesel and gasoline vehicles through detailed characterization of organic carbon emissions, P. Natl. Acad. Sci. USA, 109, 18318-18323, https://doi.org/10.1073/pnas.1212272109, 2012.

Gentner, D. R., Worton, D. R., Isaacman, G., Davis, L. C., Dallmann, T. R., Wood, E. C., Herndon, S. C., Goldstein, A. H., and Harley, R. A.: Chemical composition of gas-phase organic carbon emissions from motor vehicles and implications for ozone production, Environ. Sci. Technol., 47, 11837-11848, https://doi.org/10.1021/es401470e, 2013.

Gentner, D. R., Jathar, S. H., Gordon, T. D., Bahreini, R., Day, D. A., El Haddad, I., Hayes, P. L., Pieber, S. M., Platt, S. M., De Gouw, J., Goldstein, A. H., Harley, R. A., Jimenez, J. L., Prévôt, A. S. H., and Robinson, A. L.: Review of Urban Sec- 
ondary Organic Aerosol Formation from Gasoline and Diesel Motor Vehicle Emissions, Environ. Sci. Technol., 51, 10741093, https://doi.org/10.1021/acs.est.6b04509, 2017.

Gong, W., Makar, P. A., Zhang, J., Milbrandt, J., Gravel, S., Hayden, K. L., Macdonald, A. M., and Leaitch, W. R.: Modelling aerosolcloud-meteorology interaction: A case study with a fully coupled air quality model (GEM-MACH), Atmos. Environ., 115, 695715, https://doi.org/10.1016/j.atmosenv.2015.05.062, 2015.

Goode, J. G., Yokelson, R. J., Susott, R. A., and Ward, D. E.: Trace gas emissions from laboratory biomass fires measured by open-path Fourier transform infrared spectroscopy: Fires in grass and surface fuels, J. Geophys. Res.-Atmos., 104, 21237-21245, 1999.

Griffith, D. W. T.: Synthetic calibration and quantitative analysis of gas-phase FT-IR spectra, Appl. Spectrosc., 50, 59-70, 1996.

Griffith, D. W. T. and Galle, B.: Flux measurements of $\mathrm{NH}_{3}$, $\mathrm{N}_{2} \mathrm{O}$ and $\mathrm{CO}_{2}$ using dual beam FTIR spectroscopy and the flux-gradient technique, Atmos. Environ., 34, 1087-1098, https://doi.org/10.1016/S1352-2310(99)00368-4, 2000.

Griffith, D. W. T. and Jamie, I. M.: FTIR Spectrometry in atmospheric and trace gas analysis in Encyclopedia of Analytical Chemistry - Applications, Theory and Instrumentation, John Wiley and Sons, Ltd, Chichester, UK, 2000.

Griffith, D. W. T., Mankin, W. G., Coffey, M. T., Ward, D. E., and RieBau, A.: FTIR remote sensing of biomass burning emissions of $\mathrm{CO}_{2}, \mathrm{CO}, \mathrm{CH}_{4}, \mathrm{CH}_{2} \mathrm{O}, \mathrm{NO}, \mathrm{NO}_{2}, \mathrm{NH}_{3}$, and $\mathrm{N}_{2} \mathrm{O}$, Global biomass burning: atmospheric, alimate, and biospheric implications, MIT Press, Cambridge, MA, USA, 1991.

Grosjean, D., Grosjean, E., and Gertler, A. W.: On-road emissions of carbonyls from light-duty and heavy-duty vehicles, Environ. Sci. Technol., 35, 45-53, https://doi.org/10.1021/es001326a, 2001.

Grutter, M., Flores, E., Basaldud, R., and Ruiz-Suárez, L.G.: Openpath FTIR spectroscopic studies of the trace gases over Mexico City, Atmos. Ocean. Opt., 16, 232-236, 2003.

Grutter, M., Flores, E., Andraca-Ayala, G., and Báez, A.: Formaldehyde levels in downtown Mexico City during 2003, Atmos. Environ., 39, 1027-1034, https://doi.org/10.1016/j.atmosenv.2004.10.031, 2005.

Harley, R. A., Marr, L. C., Lehner, J. K., and Giddings, S. N.: Changes in motor vehicle emissions on diurnal to decadal time scales and effects on atmospheric composition, Environ. Sci. Technol., 39, 5356-5362, https://doi.org/10.1021/es048172+, 2005.

Hassler, B., McDonald, B. C., Frost, G. J., Borbon, A., Carslaw, D. C., Civerolo, K., Granier, C., Monks, P. S., Monks, S., Parrish, D. D., Pollack, I. B., Rosenlof, K. H., Ryerson, T. B., von Schneidemesser, E., and Trainer, M.: Analysis of long-term observations of $\mathrm{NO}_{x}$ and $\mathrm{CO}$ in megacities and application to constraining emissions inventories, Geophys. Res. Lett., 43, 9920-9930, https://doi.org/10.1002/2016GL069894, 2016.

Haugen, M. J. and Bishop, G. A.: Repeat fuel specific emission measurements on two California heavy-duty truck fleets, Environ. Sci. Technol., 51, 4100-4107, https://doi.org/10.1021/acs.est.6b06172, 2017.

Health Effects Institute (HEI): Traffic-related air-pollution: a critical review of the literature on emissions, exposure and health effects, Special Report 17, 386 pp., available at: https://www.healtheffects.org/publication/traffic-related-air- pollution-critical-review-literature-emissions-exposure-andhealth (last access: 7 November 2017), 2010.

Hong, D. W., Heo, G. S., Han, J. S., and Cho, S. Y.: Application of the open path FTIR with COL1SB to measurements of ozone and VOCs in the urban area, Atmos. Environ., 38, 5567-5576, https://doi.org/10.1016/j.atmosenv.2004.06.033, 2004.

Horrocks, L., Burton, M., Francis, P., and Oppenheimer, C.: Stable gas plume composition measured by OP-FTIR spectroscopy at Masaya Volcano, Nicaragua, 1998-,1999, Geophys. Res. Lett., 26, 3497-3500, 1999.

Hu, S., Fruin, S., Kozawa, K., Mara, S., Paulson, S. E., and Winer, A. M.: A wide area of air pollutant impact downwind of a freeway during pre-sunrise hours, Atmos. Environ., 43, 2541-2549, https://doi.org/10.1016/j.atmosenv.2009.02.033, 2009.

Huai, T., Durbin, T. D., Miller, J. W., Pisano, J. T., Sauer, C. G., Rhee, S. H., and Norbeck, J. M.: Investigation of $\mathrm{NH}_{3}$ emissions from new technology vehicles as a function of vehicle operating conditions, Environ. Sci. Technol., 37, 4841-4847, https://doi.org/10.1021/es030403+, 2003.

Janhäll, S., Olofson, K. F. G., Andersson, P. U., Pettersson, J. B. C., and Hallquist, M.: Evolution of the urban aerosol during winter temperature inversion episodes, Atmos. Environ., 40, 53555366, https://doi.org/10.1016/j.atmosenv.2006.04.051, 2006.

Jerrett, M., Finkelstein, M. M., Brook, J. R., Arain, M. A., Kanaroglou, P., Stieb, D. M., Gilbert, N. L., Verma, D., Finkelstein, N., Chapman, K. R., and Sears, M. R.: A cohort study of traffic-related air pollution and mortality in Toronto, Ontario, Canada, Environ. Health Persp., 117, 772-777, https://doi.org/10.1289/ehp.11533, 2009.

Jerrett, M., McConnell, R., Wolch, J., Chang, R., Lam, C., Dunton, G., Gilliland, F., Lurmann, F., Islam, T., and Berhane, K.: Traffic-related air pollution and obesity formation in children: A longitudinal, multilevel analysis, Environ. Health, 13, https://doi.org/10.1186/1476-069X-13-49, 2014.

Johnson, T. J., Profeta, L. T. M., Sams, R. L., Griffith, D. W. T., and Yokelson, R. L.: An infrared spectral database for detection of gases emitted by biomass burning, Vib. Spectrosc., 53, 97-102, https://doi.org/10.1016/j.vibspec.2010.02.010, 2010.

Karlsson, H. L.: Ammonia, nitrous oxide and hydrogen cyanide emissions from five passenger vehicles, Sci. Total Environ., 334 335, 125-132, https://doi.org/10.1016/j.scitotenv.2004.04.061, 2004.

Karner, A. A., Eisinger, D. S., and Niemeier, D. A.: Nearroadway air quality: Synthesizing the findings from real-world data, Environ. Sci. Technol., 44, 5334-5344, https://doi.org/10.1021/es100008x, 2010.

Kean, A. J., Harley, R. A., Littlejohn, D., and Kendall, G. R.: On-road measurement of ammonia and other motor vehicle exhaust emissions, Environ. Sci. Technol., 34, 3535-3539, https://doi.org/10.1021/es991451q, 2000.

Keirns, M. H. and Holt, E. L.: Hydrogen cyanide emissions from three-way catalyst prototypes under malfunctioning conditions, International Automotive Engineering Congress and Exposition, Detroit, MI, USA, 27 February-3 March 1978, SAE Tech. Pap., 780201, https://doi.org/10.4271/780201, 1978.

Khalifa, A., Marchetti, M., Bouilloud, L., Martin, E., Bues, M., and Chancibaut, K.: Accounting for anthropic energy flux of traffic in winter urban road surface temperature simula- 
tions with the TEB model, Geosci. Model Dev., 9, 547-565, https://doi.org/10.5194/gmd-9-547-2016, 2016.

Kim, S. W., McDonald, B. C., Baidar, S., Brown, S. S., Dube, B., Ferrare, R. A., Frost, G. J., Harley, R. A., Holloway, J. S., Lee, H. J., McKeen, S. A., Neuman, J. A., Nowak, J. B., Oetjen, H., Ortega, I., Pollack, I. B., Roberts, J. M., Ryerson, T. B., Scarino, A. J., Senff, C. J., Thalman, R., Trainer, M., Volkamer, R., Wagner, N., Washenfelder, R. A., Waxman, E., and Young, C.J.: Modeling the weekly cycle of $\mathrm{NO}_{x}$ and $\mathrm{CO}$ emissions and their impacts on $\mathrm{O}_{3}$ in the Los Angeles-South Coast Air Basin during the CalNex 2010 field campaign, J. Geophys. Res.-Atmos., 121, 1340-1360, https://doi.org/10.1002/2015JD024292, 2016.

Lee, P. K. H., Brook, J. R., Dabek-Zlotorzynska, E., and Mabury, S. A.: Identification of the major sources contributing to $\mathrm{PM}_{2.5}$ observed in Toronto, Environ. Sci. Technol., 37, 4831-4840, https://doi.org/10.1021/es026473i, 2003.

Lelieveld, J., Evans, J. S., Fnais, M., Giannadaki, D., and Pozzer, A.: The contribution of outdoor air pollution sources to premature mortality on a global scale, Nature, 525, 367-371, https://doi.org/10.1038/nature15371, 2015.

Leroyer, S., Bélair, S., Spacek, L., Filion, A. B., Winter, B., and Vallée, M.: Modeling the urban and lake-induced boundary-layers for the Greater Toronto Area, 22nd American Meteorological Society Symposium on Boundary Layers and Turbulence, 1924 June 2016, Salt Lake City, USA, 13A.8, 2016.

Lin, S., Munsie, J. P., Hwang, S. A., Fitzgerald, E., and Cayo, M. R.: Childhood asthma hospitalization and residential exposure to state route traffic, Environ. Res., 88, 73-81, https://doi.org/10.1006/enrs.2001.4303, 2002.

Lindenmaier, R., Batchelor, R. L., Strong, K., Fast, H., Goutail, F., Kolonjari, F., Thomas McElroy, C., Mittermeier, R. L., and Walker, K. A.: An evaluation of infrared microwindows for ozone retrievals using the Eureka Bruker 125HR Fourier transform spectrometer, J. Quant. Spectrosc. Ra., 111, 569-585, https://doi.org/10.1016/j.jqsrt.2009.10.013, 2010.

Liu, B. and Frey, H. C.: Variability in light-duty gasoline vehicle emission factors from trip-based real-world measurements, Environ. Sci. Technol., 49, 12525-12534, https://doi.org/10.1021/acs.est.5b00553, 2015.

Liu, Y., Liggio, J., Staebler, R., and Li, S.-M.: Reactive uptake of ammonia to secondary organic aerosols: kinetics of organonitrogen formation, Atmos. Chem. Phys., 15, 1356913584, https://doi.org/10.5194/acp-15-13569-2015, 2015.

Livingston, C., Rieger, P., and Winer, A.: Ammonia emissions from a representative in-use fleet of light and medium-duty vehicles in the California South Coast Air Basin, Atmos. Environ., 43, 3326-3333, https://doi.org/10.1016/j.atmosenv.2009.04.009, 2009.

Makar, P. A., Gong, W., Hogrefe, C., Zhang, Y., Curci, G., Žabkar, R., Milbrandt, J., Im, U., Balzarini, A., Baró, R., Bianconi, R., Cheung, P., Forkel, R., Gravel, S., Hirtl, M., Honzak, L., Hou, A., Jiménez-Guerrero, P., Langer, M., Moran, M. D., Pabla, B., Pérez, J. L., Pirovano, G., San José, R., Tuccella, P., Werhahn, J., Zhang, J., and Galmarini, S.: Feedbacks between air pollution and weather, part 2: Effects on chemistry, Atmos. Environ., 115, 499-526, https://doi.org/10.1016/j.atmosenv.2014.10.021, 2015a.

Makar, P. A., Gong, W., Milbrandt, J., Hogrefe, C., Zhang, Y., Curci, G., Žabkar, R., Im, U., Balzarini, A., Baró, R., Bianconi, R.,
Cheung, P., Forkel, R., Gravel, S., Hirtl, M., Honzak, L., Hou, A., Jiménez-Guerrero, P., Langer, M., Moran, M. D., Pabla, B., Pérez, J. L., Pirovano, G., San José, R., Tuccella, P., Werhahn, J., Zhang, J., and Galmarini, S.: Feedbacks between air pollution and weather, part 1: Effects on weather, Atmos. Environ., 115, 442-469, 2015b.

Marr, L. C. and Harley, R. A.: Spectral analysis of weekdayweekend differences in ambient ozone, nitrogen oxide, and nonmethane hydrocarbon time series in California, Atmos. Environ., 36, 2327-2335, https://doi.org/10.1016/S1352-2310(02)001887, 2002a.

Marr, L. C. and Harley, R. A.: Modeling the effect of weekdayweekend differences in motor vehicle emissions on photochemical air pollution in central California, Environ. Sci. Technol., 36, 4099-4106, https://doi.org/10.1021/es020629x, 2002b.

McConnell, R., Berhane, K., Yao, L., Jerrett, M., Lurmann, F., Gilliland, F., Künzli, N., Gauderman, J., Avol, E., Thomas, D., and Peters, J.: Traffic, susceptibility, and childhood asthma, Environ. Health Persp., 114, 766-772, https://doi.org/10.1289/ehp.8594, 2006.

Moeckli, M. A., Fierz, M., and Sigrist, M. W.: Emission factors for ethene and ammonia from a tunnel study with a photoacoustic trace gas detection system, Environ. Sci. Technol., 30, 2864 2867, https://doi.org/10.1021/es960152n, 1996.

Moran, M. D., Ménard, S., Talbot, D., Huang, P., Makar, P. A., Gong, W., Landry, H., Gravel, S., Gong, S., Crevier, L. P., Kallaur, A., and Sassi, M.: Particulate-matter forecasting with GEM-MACH15, a new Canadian air-quality forecast model, in: Air Pollution Modelling and its Application XX, edited by: Steyn, D. G. and Rao, S. T., Springer, Dordrecht, the Netherlands, 289-292, https://doi.org/10.1007/978-90-4813812-8, 2010.

Moran, M. D., Ménard, S., Pavlovic, R., Anselmo, D., Antonopoulos, S., Makar, P. A., Gong, W., Stroud, C., Zhang, J., Zheng, Q., Robichaud, A., Landry, H., Beaulieu, P.-A., Gilbert, S., Chen, J., and Kallaur, A.: Recent advances in Canada's national operational AQ forecasting system, in: Air Pollution Modeling and its Application XXII, edited by: Steyn, D. G., Builtjes, P. J. H. and Timmermans, R. M. A., Springer, Dordrecht, the Netherlands, 215-220, https://doi.org/10.1007/978-94-007-5577-2_4, 2014.

Moussa, S. G., Leithead, A., Li, S. M., Chan, T. W., Wentzell, J. J. B., Stroud, C., Zhang, J., Lee, P., Lu, G., Brook, J. R., Hayden, K., Narayan, J., and Liggio, J.: Emissions of hydrogen cyanide from on-road gasoline and diesel vehicles, Atmos. Environ., 131, 185-195, https://doi.org/10.1016/j.atmosenv.2016.01.050, 2016.

Murphy, J. G., Day, D. A., Cleary, P. A., Wooldridge, P. J., Millet, D. B., Goldstein, A. H., and Cohen, R. C.: The weekend effect within and downwind of Sacramento - Part 1: Observations of ozone, nitrogen oxides, and VOC reactivity, Atmos. Chem. Phys., 7, 5327-5339, https://doi.org/10.5194/acp-7-5327-2007, 2007.

National Air Pollution Surveillance Program of Government of Canada: NAPS Data Products, available at: http://maps-cartes. ec.gc.ca/rnspa-naps/data.aspx?lang=en, last access: 23 November 2017.

Ontario Ministry of Transportation: 2013 data, available at: http://www.raqsb.mto.gov.on.ca/techpubs/TrafficVolumes.nsf/ tvweb?OpenForm\&Seq=6 (last access: 23 November 2017), 2016. 
Oppenheimer, C. and Kyle, P. R.: Probing the magma plumbing of Erebus volcano, Antarctica, by open-path FTIR spectroscopy of gas emissions, J. Volcanol. Geoth. Res., 177, 743754, https://doi.org/10.1016/j.jvolgeores.2007.08.022, 2008.

Parrish, D. D., Trainer, M., Hereid, D., Williams, E. J., Olszyna, K. J., Harley, R. A., Meagher, J. F., and Fehsenfeld, F. C.: Decadal change in carbon monoxide to nitrogen oxide ratio in U.S. vehicular emissions, J. Geophys. Res.-Atmos., 107, ACH 5-1-ACH 5-9, https://doi.org/10.1029/2001JD000720, 2002.

Paton-Walsh, C., Smith, T. E. L., Young, E. L., Griffith, D. W. T., and Guérette, É.-A.: New emission factors for Australian vegetation fires measured using open-path Fourier transform infrared spectroscopy - Part 1: Methods and Australian temperate forest fires, Atmos. Chem. Phys., 14, 11313-11333, https://doi.org/10.5194/acp-14-11313-2014, 2014.

Pavlovic, R., Chen, J., Anderson, K., Moran, M. D., Beaulieu, P.A., Davignon, D., and Cousineau, S.: The FireWork air quality forecast system with near-real-time biomass burning emissions: Recent developments and evaluation of performance for the 2015 North American wildfire season, J. Air Waste Manage., 66, 819841, https://doi.org/10.1080/10962247.2016.1158214, 2016.

Pearson, R. L., Wachtel, H., and Ebi, K. L.: Distance-weighted traffic density in proximity to a home is a risk factor for leukemia and other childhood cancers, J. Air Waste Manage., 50, 175-180, https://doi.org/10.1080/10473289.2000.10463998, 2000.

Perrino, C., Catrambone, M., Menno Di Bucchianico, A., and Allegrini, I.: Gaseous ammonia in the urban area of Rome, Italy and its relationship with traffic emissions, Atmos. Environ., 36, 5385-5394, https://doi.org/10.1016/S1352-2310(02)004697, 2002.

Pollack, I. B., Ryerson, T. B., Trainer, M., Parrish, D. D., Andrews, A. E., Atlas, E. L., Blake, D. R., Brown, S. S., Commane, R., Daube, B. C., de Gouw, J. A., Dubé, W. P., Flynn, J., Frost, G. J., Gilman, J. B., Grossberg, N., Holloway, J. S., Kofler, J., Kort, E. A., Kuster, W. C., Lang, P. M., Lefer, B., Lueb, R. A., Neuman, J. A., Nowak, J. B., Novelli, P. C., Peischl, J., Perring, A. E., Roberts, J. M., Santoni, G., Schwarz, J. P., Spackman, J. R., Wagner, N. L., Warneke, C., Washenfelder, R. A., Wofsy, S. C., and Xiang, B.: Airborne and ground-based observations of a weekend effect in ozone, precursors, and oxidation products in the California South Coast Air Basin, J. Geophys. Res.-Atmos., 117, D00V05, https://doi.org/10.1029/2011jd016772, 2012.

Popa, M. E., Vollmer, M. K., Jordan, A., Brand, W. A., Pathirana, S. L., Rothe, M., and Röckmann, T.: Vehicle emissions of greenhouse gases and related tracers from a tunnel study: $\mathrm{CO}: \mathrm{CO}_{2}$, $\mathrm{N}_{2} \mathrm{O}: \mathrm{CO}_{2}, \mathrm{CH}_{4}: \mathrm{CO}_{2}, \mathrm{O}_{2}: \mathrm{CO}_{2}$ ratios, and the stable isotopes ${ }^{13} \mathrm{C}$ and ${ }^{18} \mathrm{O}$ in $\mathrm{CO}_{2}$ and $\mathrm{CO}$, Atmos. Chem. Phys., 14, 21052123, https://doi.org/10.5194/acp-14-2105-2014, 2014.

Rantala, P., Järvi, L., Taipale, R., Laurila, T. K., Patokoski, J., Kajos, M. K., Kurppa, M., Haapanala, S., Siivola, E., Petäjä, T., Ruuskanen, T. M., and Rinne, J.: Anthropogenic and biogenic influence on VOC fluxes at an urban background site in Helsinki, Finland, Atmos. Chem. Phys., 16, 7981-8007, https://doi.org/10.5194/acp-16-7981-2016, 2016.

Reche, C., Viana, M., Pandolfi, M., Alastuey, A., Moreno, T., Amato, F., Ripoll, A., and Querol, X.: Urban $\mathrm{NH}_{3}$ levels and sources in a Mediterranean environment, Atmos. Environ., 57, 153-164, https://doi.org/10.1016/j.atmosenv.2012.04.021, 2012.
Reyes, F., Grutter, M., Jazcilevich, A., and González-Oropeza, R.: Tecnical Note: Analysis of non-regulated vehicular emissions by extractive FTIR spectrometry: tests on a hybrid car in Mexico City, Atmos. Chem. Phys., 6, 5339-5346, https://doi.org/10.5194/acp-6-5339-2006, 2006.

Rogers, T. M., Grimsrud, E. P., Herndon, S. C., Jayne, J. T., Kolb, C. E., Allwine, E., Westberg, H., Lamb, B. K., Zavala, M., Molina, L. T., Molina, M. J., and Knighton, W. B.: On-road measurements of volatile organic compounds in the Mexico City metropolitan area using proton transfer reaction mass spectrometry, Int. J. Mass Spectrom., 252, 26-37, https://doi.org/10.1016/j.ijms.2006.01.027, 2006.

Rothman, L. S., Rinsland, C. P., Goldman, A., Massie, S. T., Edwards, D. P., Flaud, J. M., Perrin, A., Camy-Peyret, C., Dana, V., Mandin, J. Y., Schroeder, J., McCann, A., Gamache, R. R., Wattson, R. B., Yoshino, K., Chance, K. V., Jucks, K. W., Brown, L. R., Nemtchinov, V., and Varanasi, P.: The HITRAN molecular spectroscopic database and HAWKS (HITRAN Atmospheric Workstation): 1996 edition, J. Quant. Spectrosc. Ra., 60, 665710, 1998.

Rothman, L. S., Gordon, I. E., Babikov, Y., Barbe, A., Chris Benner, D., Bernath, P. F., Birk, M., Bizzocchi, L., Boudon, V., Brown, L. R., Campargue, A., Chance, K., Cohen, E. A., Coudert, L. H., Devi, V. M., Drouin, B. J., Fayt, A., Flaud, J. M., Gamache, R. R., Harrison, J. J., Hartmann, J. M., Hill, C., Hodges, J. T., Jacquemart, D., Jolly, A., Lamouroux, J., Le Roy, R. J., Li, G., Long, D. A., Lyulin, O. M., Mackie, C. J., Massie, S. T., Mikhailenko, S., Müller, H. S. P., Naumenko, O. V., Nikitin, A. V., Orphal, J., Perevalov, V., Perrin, A., Polovtseva, E. R., Richard, C., Smith, M. A. H., Starikova, E., Sung, K., Tashkun, S., Tennyson, J., Toon, G. C., Tyuterev, V., and Wagner, G.: The HITRAN2012 molecular spectroscopic database, J. Quant. Spectrosc. Ra., 130, 4-50, https://doi.org/10.1016/j.jqsrt.2013.07.002, 2013.

Rubin, J. I., Kean, A. J., Harley, R. A., Millet, D. B., and Goldstein, A. H.: Temperature dependence of volatile organic compound evaporative emissions from motor vehicle, J. Geophys. Res.Atmos., 111, D03305, https://doi.org/10.1029/2005JD006458, 2006.

Sahu, L. K. and Saxena, P.: High time and mass resolved PTRTOF-MS measurements of VOCs at an urban site of India during winter: Role of anthropogenic, biomass burning, biogenic and photochemical sources, Atmos. Res., 164-165, 84-94, https://doi.org/10.1016/j.atmosres.2015.04.021, 2015.

Sailor, D. J. and Lu, L.: A top-down methodology for developing diurnal and seasonal anthropogenic heating profiles for urban areas, Atmos. Environ., 38, 2737-2748, https://doi.org/10.1016/j.atmosenv.2004.01.034, 2004.

Seinfeld, J. H. and Pandis, S. N.: Atmospheric Chemistry and Physics: From Air Pollution to Climate Change, John Wiley \& Sons, Inc, Hoboken, New Jersey, USA, 1203 pp., 2006.

Shankardass, K., Jerrett, M., Dell, S. D., Foty, R., and Stieb, D.: Spatial analysis of exposure to traffic-related air pollution at birth and childhood atopic asthma in Toronto, Ontario, Health Place, 34, 287-295, https://doi.org/10.1016/j.healthplace.2015.06.001, 2015.

Sharpe, S. W., Johnson, T. J., Sams, R. L., Chu, P. M., Rhoderick, G. C., and Johnson, P. A.: Gas-phase databases for quantitative infrared spectroscopy, Appl. Spectrosc., 58, 1452-1461, https://doi.org/10.1366/0003702042641281, 2004. 
Smith, T. E. L., Wooster, M. J., Tattaris, M., and Griffith, D. W. T.: Absolute accuracy and sensitivity analysis of OP-FTIR retrievals of $\mathrm{CO}_{2}, \mathrm{CH}_{4}$ and $\mathrm{CO}$ over concentrations representative of "clean air" and "polluted plumes", Atmos. Meas. Tech., 4, 97116, https://doi.org/10.5194/amt-4-97-2011, 2011.

Smith, T. E. L., Paton-Walsh, C., Meyer, C. P., Cook, G. D., Maier, S. W., Russell-Smith, J., Wooster, M. J., and Yates, C. P.: New emission factors for Australian vegetation fires measured using open-path Fourier transform infrared spectroscopy - Part 2: Australian tropical savanna fires, Atmos. Chem. Phys., 14, 1133511352, https://doi.org/10.5194/acp-14-11335-2014, 2014.

Statistics Canada: Sales of fuel used for road motor vehicles, by province and territory, available at: http://www.statcan. gc.ca/tables-tableaux/sum-som/101/cst01/trade37b-eng.htm (last access: 7 November 2017), 2016.

Stedman, D. H.: Automobile carbon monoxide emission, Environ. Sci. Technol., 23, 147-149, https://doi.org/10.1021/es00179a002, 1989.

Stremme, W., Grutter, M., Rivera, C., Bezanilla, A., Garcia, A. R., Ortega, I., George, M., Clerbaux, C., Coheur, P.-F., Hurtmans, D., Hannigan, J. W., and Coffey, M. T.: Top-down estimation of carbon monoxide emissions from the Mexico Megacity based on FTIR measurements from ground and space, Atmos. Chem. Phys., 13, 1357-1376, https://doi.org/10.5194/acp13-1357-2013, 2013.

Stroud, C. A., Zaganescu, C., Chen, J., McLinden, C. A., Zhang, J., and Wang, D.: Toxic volatile organic air pollutants across Canada: multi-year concentration trends, regional air quality modelling and source apportionment, J. Atmos. Chem., 73, 137164, https://doi.org/10.1007/s10874-015-9319-z, 2016.

Stull, R. B.: An Introduction To Boundary Layer Meteorology, Kluwer Academic Publishers, Dordrecht, the Netherlands, 670 pp., 2003.

Su, J. G., Apte, J. S., Lipsitt, J., Garcia-Gonzales, D. A., Beckerman, B. S., de Nazelle, A., Texcalac-Sangrador, J. L., and Jerrett, M.: Populations potentially exposed to traffic-related air pollution in seven world cities, Environ. Int., 78, 82-89, https://doi.org/10.1016/j.envint.2014.12.007, 2015.

Suárez, M. P. and Löffler, D. G.: HCN synthesis from $\mathrm{NH}_{3}$ and $\mathrm{CH}_{4}$ on $\mathrm{Pt}$ at atmospheric pressure, J. Catal., 97, 240-242, https://doi.org/10.1016/0021-9517(86)90054-0, 1986.

Suarez-Bertoa, R., Zardini, A. A., and Astorga, C.: Ammonia exhaust emissions from spark ignition vehicles over the New European Driving Cycle, Atmos. Environ., 97, 43-53, https://doi.org/10.1016/j.atmosenv.2014.07.050, 2014.

Sutton, M. A., Dragosits, U., Tang, Y. S., and Fowler, D.: Ammonia emissions from non-agricultural sources in the UK, Atmos. Environ., 34, 855-869, https://doi.org/10.1016/S13522310(99)00362-3, 2000.

Urban, C. M. and Garbe, R. J.: Regulated and unregulated exhaust emissions from malfunctioning automobiles, International Automotive Engineering Congress and Exposition, Detroit, MI, USA, 26 February-2 March 1979, SAE Tech. Pap., 790696, https://doi.org/10.4271/790696, 1979.

Urban, C. M. and Garbe, R. J.: Exhaust emissions from malfunctioning three-way catalyst-equipped automobiles, International Automotive Engineering Congress and Exposition, Detroit, MI, USA, 25-29 February 1980, SAE Tech. Pap., 800511, https://doi.org/10.4271/800511, 1980.
U.S. EPA: MOVES2010 Highway vehicle temperature, humidity, air conditioning, and inspection and ,maintenance adjustments", EPA-420-R-10-027, available at: https://cfpub.epa.gov/ si/si_public_record_report.cfm?dirEntryID=216504 (last access: 7 November 2017), 2010a.

U.S. EPA: IRIS Toxicological review of hydrogen cyanide and cyanide salts (Final Report), U.S. Environmental Protection Agency, Washington, D.C., EPA/635/R-08/016F, 108 pp., available at: https://cfpub.epa.gov/ncea/risk/recordisplay.cfm?deid= $227766 \&$ CFID $=79548176 \&$ CFTOKEN=33756592 (last access: 7 November 2017), 2010b.

U.S. EPA: Criteria pollutants National Tier 1 for 1970-2016, Data in MS Excel, available at: https://www.epa.gov/ air-emissions-inventories/air-pollutant-emissions-trends-data (last access: 31 March 2017), 2016.

Voorhoeve, R. J. H., Patel, C. K. N., Trimble, L. E., and Kerl, R. $\mathrm{J}$.: Hydrogen cyanide production during reduction of nitric oxide over platinum catalysts, Science, 190, 149-151, 1975.

Wallace, H. W., Jobson, B. T., Erickson, M. H., McCoskey, J. K., VanReken, T. M., Lamb, B. K., Vaughan, J. K., Hardy, R. J., Cole, J. L., Strachan, S. M., and Zhang, W.: Comparison of wintertime $\mathrm{CO}$ to $\mathrm{NO}_{x}$ ratios to MOVES and MOBILE6.2 on-road emissions inventories, Atmos. Environ., 63, 289-297, https://doi.org/10.1016/j.atmosenv.2012.08.062, 2012.

Warneke, C., McKeen, S. A., de Gouw, J. A., Goldan, P. D., Kuster, W. C., Holloway, J. S., Williams, E. J., Lerner, B. M., Parrish, D. D., Trainer, M., Fehsenfeld, F. C., Kato, S., Atlas, E. L., Baker, A., and Blake, D. R.: Determination of urban volatile organic compound emission ratios and comparison with an emissions database, J. Geophys. Res.-Atmos., 112, D10S47, https://doi.org/10.1029/2006JD007930, 2007.

Warneke, C., De Gouw, J. A., Edwards, P. M., Holloway, J. S., Gilman, J. B., Kuster, W. C., Graus, M., Atlas, E., Blake, D., Gentner, D. R., Goldstein, A. H., Harley, R. A., Alvarez, S., Rappenglueck, B., Trainer, M., and Parrish, D. D.: Photochemical aging of volatile organic compounds in the Los Angeles basin: Weekday-weekend effect, J. Geophys. Res.-Atmos., 118, 50185028, https://doi.org/10.1002/jgrd.50423, 2013.

Wu, R. T., Chang, S.-Y., Chung, Y .W., Tzou, H. C., and Tso, T.-L.: FTIR remote sensor measurements of air pollutants in the petrochemical industrial park, Proc. SPIE 2552, Infrared Technology XXI, San Diego, CA, USA, 719-727, 1995.

Yao, X., Hu, Q., Zhang, L., Evans, G. J., Godri, K. J., and Ng, A. C.: Is vehicular emission a significant contributor to ammonia in the urban atmosphere?, Atmos. Environ., 80, 499-506, https://doi.org/10.1016/j.atmosenv.2013.08.028, 2013.

Yokelson, R. J.: Emissions of formaldehyde, acetic acid, methanol, and other trace gases from biomass fires in North Carolina measured by airborne Fourier Transform Infrared spectroscopy, J. Geophys. Res.-Atmos., 104, 30109-30125, 1999.

Yokelson, R. J., Griffith, D. W. T., and Ward, D. E.: Openpath Fourier Transform Infrared studies of large-scale laboratory biomass fires, J. Geophys. Res.-Atmos., 101, 21067-21080, 1996.

Yokelson, R. J., Susott, R., Ward, D. E., Reardon, J., and Griffith, D. W. T.: Emissions from smoldering combustion of biomass measured by open-path Fourier Transform Infrared spectroscopy, J. Geophys. Res.-Atmos., 102, 18865-18877, 1997. 
Yokelson, R. J., Karl, T., Artaxo, P., Blake, D. R., Christian, T. J., Griffith, D. W. T., Guenther, A., and Hao, W. M.: The Tropical Forest and Fire Emissions Experiment: overview and airborne fire emission factor measurements, Atmos. Chem. Phys., 7, 5175-5196, https://doi.org/10.5194/acp-7-5175-2007, 2007.

Yokelson, R. J., Christian, T. J., Karl, T. G., and Guenther, A.: The tropical forest and fire emissions experiment: laboratory fire measurements and synthesis of campaign data, Atmos. Chem. Phys., 8, 3509-3527, https://doi.org/10.5194/acp-8-3509-2008, 2008.

Yokelson, R. J., Burling, I. R., Gilman, J. B., Warneke, C., Stockwell, C. E., de Gouw, J., Akagi, S. K., Urbanski, S. P., Veres, P., Roberts, J. M., Kuster, W. C., Reardon, J., Griffith, D. W. T., Johnson, T. J., Hosseini, S., Miller, J. W., Cocker III, D. R., Jung, H., and Weise, D. R.: Coupling field and laboratory measurements to estimate the emission factors of identified and unidentified trace gases for prescribed fires, Atmos. Chem. Phys., 13, 89-116, https://doi.org/10.5194/acp-13-89-2013, 2013.
Zhang, J., Zheng, Q., Moran, M. D., Gordon, M., Liggio, J., Makar, P., Stroud, C., and Taylor, B.: Improvements to SMOKE processing of Canadian on-road mobile emissions, 20th Emissions Inventory Conference, 13-16 August 2012, Tampa, USA, 13 pp., available at: http://www.epa.gov/ttn/chief/conference/ ei20/session1/jzhang.pdf (last access: 7 November 2017), 2012.

Zhang, K., Batterman, S., and Dion, F.: Vehicle emissions in congestion: Comparison of work zone, rush hour and free-flow conditions, Atmos. Environ., 45, 1929-1939, https://doi.org/10.1016/j.atmosenv.2011.01.030, 2011.

Zhou, Y. and Levy, J.I.: Factors influencing the spatial extent of mobile source air pollution impacts: a meta-analysis, BMC Public Health, 7, 89, https://doi.org/10.1186/1471-2458-7-89, 2007. 